\title{
BANKER PREFERENCES, INTERBANK CONNECTIONS, AND THE ENDURING STRUCTURE OF THE FEDERAL RESERVE SYSTEM
}

\author{
Matthew S. Jaremski \\ David C. Wheelock \\ Working Paper 21553 \\ http://www.nber.org/papers/w21553 \\ NATIONAL BUREAU OF ECONOMIC RESEARCH \\ 1050 Massachusetts Avenue \\ Cambridge, MA 02138 \\ September 2015
}

The authors thank Michael Bordo, Mark Carlson, David Hammes, Tom Garrett, Michael McAvoy, land Mary Rodgers for comments, data and other information used in preparing this paper. Views expressed herein do not necessarily represent official positions of the Federal Reserve Bank of St. Louis, the Federal Reserve System, or the National Bureau of Economic Research.

NBER working papers are circulated for discussion and comment purposes. They have not been peerreviewed or been subject to the review by the NBER Board of Directors that accompanies official NBER publications.

(C) 2015 by Matthew S. Jaremski and David C. Wheelock. All rights reserved. Short sections of text, not to exceed two paragraphs, may be quoted without explicit permission provided that full credit, including (๑) notice, is given to the source. 
Banker Preferences, Interbank Connections, and the Enduring Structure of the Federal Reserve System

Matthew S. Jaremski and David C. Wheelock

NBER Working Paper No. 21553

September 2015

JEL No. E58,N21,N22

\begin{abstract}
$\underline{\text { ABSTRACT }}$
Established by a three person Reserve Bank Organization Committee (RBOC) in 1914, the structure of the Federal Reserve System has remained essentially unchanged ever since, despite criticism at the time and over ensuing decades. This paper examines the selection of cities for Reserve Banks and branches, and of district boundaries. We show that each aspect of the Fed's structure reflected the preferences of national banks, including adjustments to district boundaries after the Fed was established. Further, using newly-collected information on the locations of each national bank's correspondents, we find that banker preferences mirrored established interbank connections. The Federal Reserve was thus formed on top of the structure that it was meant to replace.
\end{abstract}

Matthew S. Jaremski

Colgate University

Department of Economics

13 Oak Drive

Hamilton, NY 13346

and NBER

mjaremski@colgate.edu

David C. Wheelock

Research Division

Federal Reserve Bank of St. Louis

P.O. Box 442

St. Louis, MO 63166-0442

david.c.wheelock@stls.frb.org 
$\underline{\text { Introduction }}$

The Federal Reserve System recently reached a centennial milestone. President Woodrow Wilson signed the Federal Reserve Act on December 23, 1913. The Act assigned to a Reserve Bank Organization Committee (RBOC) the task of determining the number of Federal Reserve districts (between eight and twelve), the boundaries of each district, and the location of a Reserve Bank within each district. The RBOC acted quickly, announcing the selection of 12 cities for Reserve Banks and the locations of district boundaries on April 2, 1914. The choices made by the RBOC were criticized at the time and are widely viewed as out of date today. The Federal Reserve districts west of the Mississippi River are much larger in area than eastern districts. In the Northeast, four Reserve Banks (Boston, New York, Philadelphia and Cleveland) are located within just a few hundred miles of each other, whereas four other Banks (Minneapolis, Kansas City, Dallas and San Francisco) serve nearly the entire western two-thirds of the country. Some cities, such as New York City, Chicago, and San Francisco were obvious choices for Reserve Banks. However, the selection of others, including Richmond, Cleveland and Kansas City were criticized by representatives of cities that believed their claims were stronger, such as Baltimore, Cincinnati, and Denver. Despite calls for reorganization at various times in its history, the structure of the Federal Reserve System has remained largely fixed since 1914, with only minor adjustments to district borders and branches but no changes in the locations of Reserve Banks. ${ }^{1}$

This paper reexamines the structure of the Federal Reserve System, including the selection of Reserve Bank cities, district boundaries and branch office locations. These locations have proved important historically. Commercial banks rely on the Federal Reserve Banks for

\footnotetext{
${ }^{1}$ Over the years, various proposals have been made to restructure the Federal Reserve to account for the shift of population to the West. Recent examples include Bordo (2015), Dearie (2015), and Fisher (2015). The chairman of the Senate Banking Committee, Richard Shelby (R-AL), introduced legislation on May 12, 2015 calling for the establishment of an independent commission to review and suggest possible changes to the structure of the Federal Reserve System, including to the number and location of Federal Reserve Banks and district boundaries.
} 
payments services and liquidity in times of need. ${ }^{2}$ The Fed's performance in carrying out these functions has real economic consequences. For example, during the Great Depression, the Atlanta Reserve Bank's liberal lending policy resulted in superior economic performance in the portion of Mississippi served by the Atlanta Bank than in the portion served by the St. Louis Reserve Bank, which was more conservative (Richardson and Troost, 2009; Ziebarth, 2013). Further, the establishment of a Reserve Bank appears to have conveyed long-term economic benefits on at least some of the cities where they were located (Odell and Weiman, 1998).

There remains a debate about the criteria that the RBOC used to select the locations of Reserve Banks and district boundaries. The RBOC asked national banks to name their top three choices for the location of their Reserve Bank, and studies conclude that the RBOC relied heavily on the results of this survey (e.g., Odell and Weiman, 1998; Meltzer, 2003; McAvoy, 2006; Binder and Spindel, 2013). However, studies disagree about other criteria that influenced the RBOC's decisions. Moreover, most studies examine only the selection of cities for Reserve Banks and do not consider the location of district boundaries or branch offices. McAvoy (2004) is a notable exception that finds that the territories assigned to Federal Reserve districts generally align with the responses of national banks to the RBOC survey, though does not examine the relationship against alternative hypotheses.

The literature has almost entirely ignored the establishment of branches of Reserve Banks. The authors of the Federal Reserve Act clearly anticipated the need for branch offices. As Carter Glass explained in April 1914: "The banking operations and the commercial transactions of any given territory will be practically maintained as they exist today, for the reason that such

\footnotetext{
${ }^{2}$ The Federal Reserve Act required all banks with federal charters, i.e., national banks, to become members of the Federal Reserve. Membership was made optional for state chartered banks. Fed services and discount window loans were generally not available to nonmember banks until the Monetary Control Act of 1980 granted access to all depository institutions.
} 
territory will transact its business with the branch bank instead of the Regional Reserve Bank, if more convenient" (Weed, 1914, p. 4). ${ }^{3}$ The RBOC likely considered possible branch locations when it selected cities for Reserve Banks and delineated district boundaries. In forming most districts, the RBOC had no choice but to combine territories whose national banks favored different cities for the location of a Reserve Bank. The subsequent establishment of branch offices thus linked more banks with their preferred city and helped knit together distinct markets within Reserve districts. In addition, the establishment of branches seems to have encouraged state-chartered banks to join the Federal Reserve System. ${ }^{4}$ Hence, an examination of all components of the Fed's structure in one comprehensive study helps to better understand the organization of the System as a whole.

We confirm that the responses of national banks to the RBOC survey were important for structuring the Federal Reserve System. Both the total number of votes and county-level tallies help explain the cities chosen for Reserve Banks, regardless of the control variables included in the model. The votes also help explain the location of branches of Reserve Banks. Some of the first cities selected for branches, such as Baltimore and Cincinnati, received many votes but ultimately were passed over for Reserve Banks. Further, we find that county-level vote totals help explain district boundaries. A few districts were comprised almost entirely of counties whose banks had favored a single city, such as New York City, Philadelphia and Chicago. However, other districts were constructed by joining together contiguous blocs of counties that had voted for different cities (many of which soon became the locations of branch offices).

\footnotetext{
${ }^{3}$ Glass sponsored the legislation that became the Federal Reserve Act in the House of Representatives. He has long been identified as the "father" of the Federal Reserve System (http://www.federalreservehistory.org/People/DetailView/14).

${ }^{4}$ Tippetts (1929) reports that many state banks joined the Federal Reserve System only after the opening of a nearby branch office.
} 
Moreover, subsequent adjustments in district boundaries better aligned districts with the countylevel vote totals.

Despite the emphasis of previous studies on how the preferences of national banks helped shape the structure of the Federal Reserve System, researchers have not systematically investigated the underlying determinants of those preferences. However, in a study about the establishment of Federal Reserve Banks in Atlanta and Dallas, Odell and Weiman (1998) note that leading banks in Atlanta and Dallas had developed substantial correspondent banking businesses by the early $20^{\text {th }}$ Century, holding deposits and providing services for banks located in their respective regions. Further, both cities were top choices for Reserve Banks among national banks in their regions, suggesting that correspondent ties may have helped Atlanta and Dallas garner support from national banks already accustomed to doing business with financial institutions in those cities.

Given their importance for the System's structure, we investigate the determinants of the votes of national banks for individual cities. Using information on the locations of the correspondents of all U.S. national banks as reported in the Rand McNally Bankers Directory of January 1913, we find that established correspondent linkages explain national bank votes. Specifically, both the total number of votes for a city and the number of counties in which it garnered the most first-choice votes are explained well by the number of correspondent links to that city. The Federal Reserve thus was formed on top of the existing interbank network structure that it was meant to replace.

The next section discusses why the Federal Reserve was established, focusing especially on how the System's geographically-decentralized structure was designed to overcome flaws of the banking system that were seen as contributing to instability. Subsequent sections examine (1) 
the selection of cities for Federal Reserve Banks and branches, (2) the delineation of Reserve district boundaries, and (3) the importance of established correspondent relationships for explaining the expressed preferences of national banks for the location of Federal Reserve Banks.

Why the Fed has a Geographically-Decentralized Structure

The Federal Reserve System was established to overcome features of the U.S. banking and payments systems that contemporaries viewed as contributing to banking panics. Those problems included an "inelastic" currency stock and the concentration of the nation's bank reserves in New York City and other money centers (Bordo and Wheelock, 2013). ${ }^{5}$

Two features of the U.S. banking system encouraged the nation's bank reserves to concentrate in large banks in New York City and a few other cities. First, unit banking laws restricted most banks to a single office location. ${ }^{6}$ Interbank relationships were thus necessary to operate the payments system, and banks often held deposits with correspondent banks in large financial centers to make payments and to collect checks and drafts on distant locations. Second, the National Banking Acts allowed most national banks to apply their deposits with correspondents in large cities toward their legal reserve requirements. Only national banks in designated central reserve cities - New York City, Chicago, and St. Louis - were required to fully satisfy their requirement by holding reserves in the form of lawful money (e.g., gold coin) in their vaults.

Reflecting the importance of agriculture in many areas of the country, the demands for money and credit were highly seasonal and somewhat varied across regions. The interbank

\footnotetext{
${ }^{5}$ The National Monetary Commission's final report in 1911 lists seventeen defects of the American banking system, most of which pertained to liquidity risk across seasons or the nation's inefficient monetary system (https://fraser.stlouisfed.org/scribd/?title_id=641\&filepath=/docs/historical/nmc/nmc_243_1912.pdf\#scribd-open). ${ }^{6}$ Even among the few states that allowed branching, most restricted branching to a bank's home city or county (Carlson and Mitchener 2006).
} 
network allowed banks throughout the country to hold surplus funds on deposit with correspondents in the larger cities and draw down their balances or borrow from their correspondents when local demands for money and credit were high (e.g., James, 1978; James and Weiman, 2010). The network ordinarily functioned well since the timing of the harvest varied somewhat across regions, though "seasonal stringency" in money markets was a perennial challenge. Moreover, the network transmitted shocks across the banking system when demand for liquidity spiked and money center banks were forced to suspend deposit withdrawals, as in the Panics of 1893 and 1907 (Kemmerer, 1910; Sprague, 1910; Calomiris and Gorton, 1991; Wicker, 2000; Carlson and Wheelock, 2015).

Reform proponents sought to make the banking system less vulnerable to shocks by protecting local markets from disruptions elsewhere in the system. Although the option of allowing banks to branch throughout the country was proposed, branching was not politically feasible, particularly in light of concerns about a "money trust." ${ }^{7}$ Instead, Congress sought to lessen both the banking system's dependence on the interbank market and the central role of the major New York City banks in particular by establishing a system of relatively autonomous Federal Reserve districts that were less vulnerable to disruption from elsewhere in the system. ${ }^{8}$ Accordingly, the Federal Reserve Act called for the establishment of eight to twelve districts, each with a Reserve Bank to hold the legal reserves of its member banks, "rediscount" their

\footnotetext{
${ }^{7}$ The Pujo Committee hearings (May 1912 to January 1913) reflected this fear of concentrated bank power. This congressional subcommittee was called to investigate the concern that a small group of New York City banks (particularly J.P. Morgan) controlled an excessively large share of bank assets either through their ownership or management. The committee's reports are available from the Federal Reserve Bank of St. Louis (https://fraser.stlouisfed.org/title/?id=80).

${ }^{8}$ For instance, the RBOC (1914a, p.15) stated: "The very essence of the new plan is intended to meet the condition which in the past has caused chief trouble by eliminating this necessity of interdependence between districts. The Federal Reserve Act will presumably afford a means of making each district selfsupporting in a credit way so that assuming the plan to work as it is expected to work the need for mutual seasonal aid and shipments of currency will be minimized."
} 
commercial and agricultural loans (and thereby furnish "elastic" supplies of currency and reserves), and operate the payments system. ${ }^{9}$

The Federal Reserve Act assigned the task of designating the locations of Federal Reserve Banks and district borders to the RBOC, which consisted of Secretary of the Treasury William McAdoo, Secretary of Agriculture David Houston, and Comptroller of the Currency John Skelton Williams. The Act provided the Committee with little explicit guidance, except "That the districts shall be apportioned with due regard to the convenience and customary course of business and shall not necessarily be conterminous with any State or Sates" (38 Stat. 251, Section 2, paragraph 1). The only true constraint was on the minimum size of Reserve Banks. The Act specified that "No Federal reserve bank shall commence business with a subscribed capital less than $\$ 4,000,000$ " (Section 2, paragraph 14), which effectively established a lower bound on the size of districts. Seen in Figure 1, the geographic distribution of the number and size of national banks in 1914 dictated that districts covering southern and western states would have to be large in area to encompass enough banks to support a Reserve Bank.

The RBOC received proposals from 37 cities seeking Reserve Banks and held public hearings in 18 cities. Bankers and other civic boosters supported their proposals by offering information about the size and strength of their local banks, the extent of their transportation and communications linkages with other cities, and by presenting testimonials from bankers and businessmen from throughout their regions in support of their city's bid for a Reserve Bank. ${ }^{10}$

\footnotetext{
${ }^{9}$ At the time, most loans were made on a discount basis. A member bank could obtain additional reserves or currency by rediscounting loans with its Reserve Bank. An amendment to the Federal Reserve Act in 1917 permitted direct loans ("advances") from Reserve Banks to their member banks, collateralized by loans that were acceptable for rediscount. See Hackley (1973) for a legal history of Federal Reserve Bank lending.

${ }^{10}$ Transcripts of RBOC hearings and other documentation are available from the Federal Reserve Bank of St. Louis (https://fraser.stlouisfed.org/theme/\#!14).
} 
The RBOC also solicited the preferences of the System's future member banks directly.

Specifically, the RBOC requested all national banks to 1) name their first, second and third choices for the location of their Reserve Bank, and 2) to recommend eight to twelve cities (in no particular order) across the country for Reserve Banks. ${ }^{11}$

On April 2, 1914, the RBOC announced that twelve districts would be formed, identified the boundaries of those districts, and named the cities that would have Reserve Banks. ${ }^{12}$ By November 1914, the Reserve Banks were open for business. The RBOC (1914a) listed several criteria that had guided its decisions. In addition to noting that each district must include enough member banks to furnish the minimum $\$ 4$ million required to capitalize a Reserve Bank, the RBOC sought to provide a "fair and equitable division of the available capital for the Federal Reserve banks among the districts created" (p. 4). The RBOC further stressed the importance of the "mercantile, industrial, and financial connections existing in each district and the relations between the various portions of the district and the city selected for the location of the Federal Reserve bank," and "the geographical situation of the district, transportation lines, and the facilities for speedy communication between the Federal Reserve bank and all portions of the district” (pp. 3-4). ${ }^{13}$

The Federal Reserve began to establish branches almost from the System's inception. Between 1914 and 1920, the Federal Reserve Board authorized 24 branches at the request of Reserve Banks and their member commercial banks. A few more branches were authorized in

\footnotetext{
${ }^{11}$ The RBOC seems to have discounted the latter recommendations, noting that a few cities that were recommended many times (e.g., Denver and New Orleans) had little local support (RBOC, 1914a).

${ }^{12}$ The RBOC did not explain its decision to establish the maximum 12 districts allowed under the Federal Reserve Act. According to Hammes (2001), H. Parker Willis "strongly recommended" a 12-district plan in a report he drafted as chair of a technical committee appointed to advise the RBOC, though later Willis (1923) wrote that it might have been more "convenient" to have formed only nine districts. Conceivably, the RBOC created 12 districts in an effort to bolster political support for the System and to dilute the influence of large city bankers, who generally preferred a System comprised of a small number of large districts.

${ }^{13}$ See McAvoy (2004; 2006), Binder and Spindel (2013) or Federal Reserve Bank of St. Louis (2014, pp. 53-81) for additional information about the RBOC and its selection of Reserve Bank cities and districts.
} 
ensuing years, but the vast majority of the system was in place by 1920 . The branches provided a full range of payments services, cash delivery, and discount window loans to member banks under the direction of the Reserve Bank and a local board of directors. According to Carter Glass, "For practical purposes the branch banks are the real working elements of the system. It is these branch banks which, in most instances, do the rediscounting” (Weed 1914, p. 3). Typically, branches were opened in cities that were distant from the Reserve Bank, and thus were more common in larger districts. $^{14}$

\section{Banker Preferences and the Selection of Reserve Bank and Branch Locations}

Several studies have concluded that the RBOC weighed heavily the results of its survey of national banks in selecting Reserve Bank cities (e.g., Bensel, 1984; McAvoy, 2004, 2006; Binder and Spindel, 2013). Table 1 lists the total number of "first-choice" votes for every city that received at least 10 first-choice votes in the RBOC survey, as well as information gleaned from unpublished county-level maps prepared by RBOC staff. ${ }^{15}$ The maps indicate the number of first-choice votes cast in each county for each city, allowing us to calculate the total firstchoice votes and number of counties "won" by each city. Because the maps were preliminary tallies prepared by the RBOC staff before all votes had been received, the vote totals shown on the maps are less than the totals given in published RBOC reports. However, the ranking of cities based on the county-level data from the maps and the reported vote totals are similar. ${ }^{16}$ Although the maps provide incomplete data on the total number of votes cast for each city, they appear to

\footnotetext{
${ }^{14}$ For example, whereas no branches were opened in the First (Boston) or Third (Philadelphia) districts, five were eventually opened in both the Fifth (Atlanta) and Twelfth (San Francisco) districts.

${ }^{15}$ The maps are located with other RBOC materials in Records of the Federal Reserve System, 1878-1996, Record Group 82, National Archives and Records Administration, which are available from the Federal Reserve Bank of St. Louis (https://fraser.stlouisfed.org/archival/\#!1344). See McAvoy (2004) for examples of the state maps and more information about their preparation.

${ }^{16}$ The maps also frequently lack votes for counties with major cities (e.g., Kings, New York, and Queens counties all were listed as only having a single vote), likely because those cities were the top choice among most banks located in the county and, hence, there was no need to indicate the relative strength of support for the city.
} 
provide a reliable indication of the city that received the most support from banks within each county. Hence, our empirical analysis uses the maps to identify the winning city for each county, defined as the city that received the most first-choice votes from national banks located in the county.

Table 1 identifies the 37 cities that requested Reserve Banks (which includes both Minneapolis and St. Paul, and Dallas and Fort Worth), the 12 cities chosen for Reserve Banks, and the cities that subsequently were chosen for branches of Reserve Banks. ${ }^{17}$ The twelve cities selected for Reserve Banks had considerable support from national banks. All were among the top eighteen in first-choice votes, and nine were among the top twelve vote recipients. With the exception of Cleveland (which received fewer first-choice votes than either Pittsburgh or Cincinnati), the RBOC located a Reserve Bank in the city that received the most votes in each district that it formed.

Banker preferences likely also influenced the selection of branch cities because branches were established at the request of the Reserve Banks and their members, and because two RBOC members-Treasury Secretary McAdoo and Comptroller of the Currency Williams were also original members of the Federal Reserve Board. ${ }^{18}$ By 1920, branches had been placed in 15 of the 20 cities with the most first-place votes other than those chosen for Reserve Banks. Branches were quickly established in cities that by all accounts were strong contenders for Reserve Banks, such as Baltimore, Cincinnati and Pittsburgh. Branches were also opened in several medium-

\footnotetext{
${ }^{17}$ The RBOC recorded separate votes for each city of the following pairs: Minneapolis and St. Paul; Dallas and Fort Worth; Kansas City, Kansas and Kansas City, Missouri; and New York City and Brooklyn. However, we combine the pairs under the assumption that the selection of one city would exclude the other from consideration. Note that these combinations allow us to count many first-choice votes that listed both cities. For instance, 44 votes specified the "Twin Cities" or "Minneapolis or St. Paul," which we have included in the vote total for Minneapolis/St. Paul.

${ }^{18}$ McAdoo was a member of the Federal Reserve Board until December 15, 1918. Williams served until May 2, 1921. Carter Glass succeeded McAdoo as Treasury Secretary and was a member of the Federal Reserve Board from December 16, 1918 to February 1, 1920.
} 
sized cities that had received substantial numbers of votes and were located some distance from the headquarters of their districts, such as Denver, Los Angeles, Louisville, and New Orleans. Empirical Model of Selection of Reserve Banks and Branch Cities

To test the importance of the RBOC survey on the selection of cities for Reserve Banks, we estimate a linear probability model using information about the 35 cities that requested a Bank. The model controls for various other economic and political variables that could plausibly have also influenced the selection of cities for Reserve Banks. ${ }^{19}$ To provide a comprehensive examination of different hypotheses concerning the choice of cities for Reserve Banks, we start with the combined set of variables used by McAvoy (2006) and Binder and Spindel (2013), which include a variety of controls for banker preferences, economic and financial development, and political considerations. To these, we add newly collected information on correspondent relationships and state bank capital. By including a large number of variables, we lessen the chance that a plausible alternative to the national bank votes explains the selection of cities for Reserve Banks and branches. Table 2 presents each variable's definition, corresponding hypothesis, and data sources.

The model takes the following form:

$$
\text { ReserveCity }_{i}=a+\beta_{1} \text { Votes }_{i}+\beta_{2} X_{i}+\beta_{3} \text { Correspondents }_{i}+e_{i}
$$

\footnotetext{
${ }^{19}$ We use a linear probability model (LPM) rather than logit or probit for both technical and practical reasons. The relatively small number of observations (12 cities chosen for Reserve Banks among 35 applicants) and additional restrictions of a nonlinear model prevent the simultaneous inclusion of all variables necessary to test comprehensively different hypotheses about the selection of Reserve Bank cities in such a model. When we estimate a logit or probit model on a subset of variables, we always find that coefficients on national bank votes are statistically and economically significant, regardless which other variables are included. However, the constraint that predicted values fall between 0 and 1 in the nonlinear models results in instability in coefficient values when the model is fully determined (though the coefficients on the voting variables retain statistical significance). Angrist and Pischke (2009) and Wooldridge (2010) support the use of a LPM to estimate marginal effects. Similarly, we report LPM results for other regressions in the paper, but obtain qualitatively similar results when using nonlinear models for the other binary regressions.
} 
where ReserveCity $y_{i}$ is a dummy variable that takes the value 1 if a Reserve Bank was placed in City $i$, Votes $i$ is either the logarithm of total first-choice votes for City $i$ or the log of the number of counties "won" by City $i$ (i.e., number of counties in which the city received a plurality of first-choice votes), $X_{i}$ is a vector of city and state-level census and political variables, Correspondents $_{i}$ is the logarithm of the number of unique bank-to-bank links between City $i$ and all other locations, ${ }^{20}$ and $e_{i}$ is a vector of Huber-White corrected standard errors.

We estimate a similar equation for the selection of branch cities, but expand the sample to include all non-Reserve Bank cities with at least 30,000 people in 1910 and add a set of district dummy variables. The changes are necessary to realistically capture the decision-making process behind establishing a branch. A branch could have been opened in any large city, and districts covering larger areas were more likely to need branches. The model is:

$$
\text { BranchCity }_{i}=a+\beta_{1} \text { Votes }_{i}+\beta_{2} X_{i}+\beta_{3} \text { Correspondents }_{i}+d_{i}+e_{i}
$$

where BranchCity $_{i}$ is a dummy variable that takes the value 1 if a branch was opened in City $i$ before $1920, d_{i}$ is a vector of district dummy variables, and the rest of the variables retain their aforementioned definitions.

Table 3 presents coefficient estimates for Equations (1) and (2). The first five columns pertain to the selection of Reserve Bank cities and the remaining five pertain to the selection of branch cities. The estimation results strongly support the hypothesis that banker preferences influenced the selection of both Reserve Bank and branch cities, regardless whether we measure preferences using the number of first-choice votes or number of counties won. The estimates indicate that doubling the number of votes received would increase the probability of a city's being chosen for a Reserve Bank by 16.9 percent and the probability of being chosen for a

\footnotetext{
${ }^{20}$ The variable is based only on correspondents of national banks. Our definition accounts for national banks that had multiple correspondents in a single city and thus captures the intensity of the links to a given city. However, results are qualitatively similar if we define the variable as the number of banks that had at least one link to a city.
} 
branch by 15.8 percent. The statistical significance of the voting variables is reduced, however, when the number of correspondent links is also included in the model, suggesting that the variables capture similar influences. Conceivably, many bankers voted for cities where they already had established correspondent relationships, which we test in various ways below.

We find some support for the view that politics played a role in locating Reserve Banks and branches, as indicated by positive and statistically significant coefficients on the number of representatives a state had on Congressional banking committees. That said, any effect of committee membership was likely small. First, the selection of Reserve Bank and branch cities align closely with the national bank votes. Second, membership on the banking committees was highly correlated with the size of a state's banking sector. For instance, 13 of the 14 states with the most total national bank capital had at least one representative or senator on a banking committee, and together they made up over half of the membership of both committees. ${ }^{21}$ Thus, membership on the banking committees likely was correlated with aspects of a state's banking sector not directly captured in the model, such as lending or deposit volumes or other services. Moreover, the banking committee variable is no longer significant for the choice of Reserve Bank cities if New York, which had three representatives on the House and Senate banking committees, is dropped from the estimation. New York City was undoubtedly going to get a Reserve Bank; the real decisions for the RBOC concerned the location of the other Banks and district boundaries.

We find some differences in the effects of other variables on the selection of Reserve Bank and branch cities. For Reserve Banks, growth in national bank capital is important when

\footnotetext{
${ }^{21}$ The states with the largest number of committee members (New York and Minnesota) were also highly ranked in terms of national bank capital (first and tenth respectively). The banking committees are also correlated with voting patterns as the 13 cities with the most votes were all in states that had at least one member on the banking committees, and New York was one of two states with three members.
} 
not controlling for correspondent links. For branch locations, the level and growth of city population is important, as is distance to the district's Reserve Bank. A city was more likely to obtain a branch, the larger its 1910 population and growth over the preceding decade, and the farther it was from the district's headquarters. The negative and statistically significant coefficient on telephones per capita is something of a puzzle and likely spurious. Because the number of telephones per capita is included to capture the development of local communications, we would anticipate it to have a positive impact on the selection of cities for Reserve Banks and branches. However, the data are observed at the state-level, rather than city level, which makes the variable a less than ideal measure of a city's communications infrastructure. Further, the apparent influence of telephones per capita on the selection of branch cities is driven entirely by the St Louis district. ${ }^{22}$

$\underline{\text { Banker Preferences and Reserve District Boundaries }}$

Our regression results support the view that the RBOC survey of national banks strongly influenced the selection of Reserve Bank and branch cities. As McAvoy (2004) argues, the survey was likely also important for the setting of district boundaries. Some evidence for this conjecture is presented in Table 4, which reports the percentage of counties in each district whose national banks had favored 1) the city selected by the RBOC for the Reserve Bank in their district, and 2) a city selected for a branch office in their district. We omit counties with no recorded votes. $^{23}$

\footnotetext{
${ }^{22}$ While both Illinois and Missouri had high numbers of telephones per capita, the selection of Chicago, St. Louis and Kansas City for Reserve Banks limited the need for branches in either state. Instead, branches of the St. Louis Bank were established in Arkansas, Kentucky and Tennessee - all states that had relatively few telephones per capita. The coefficient on the telephones variable becomes statistically insignificant if those states are omitted from estimation.

${ }^{23}$ Many of the counties without votes were in the West and had neither a national bank nor large city. The percentages when all counties are included or using modern Federal Reserve boundaries are available from the authors upon request.
} 
The table shows that the twelve cities chosen for Reserve Banks were the preferred choice of national banks in 55 percent of all counties (with recorded votes) included in their districts. Perhaps not surprisingly, New York City was the first choice among banks in all 60 counties assigned to the New York district. Boston, Chicago, Minneapolis and Philadelphia were the first choice in over 70 percent of the counties assigned to their districts as well. However, the cities selected for Reserve Banks in all other districts were the top choices of no more than half the counties in their districts. In forming those districts, the RBOC merged blocs of counties that had supported different cities. Branch offices were subsequently opened in many cities that had won sizable blocs of counties but were not chosen for a Reserve Bank. For example, Cleveland won only 22 percent of the 136 counties assigned to its district. However, Cincinnati and Pittsburgh — the two cities in the district where branches were subsequently located — together won 60 percent of the district's counties, and thus the three cities together won 82 percent of counties assigned to the Cleveland district. Across all Federal Reserve districts, the RBOC assigned 84 percent of the 1,847 counties with at least one recorded vote to a district that included either the Reserve Bank city or a branch city favored by a plurality of the county's national banks. $^{24}$

In forming districts, the RBOC sought to maintain "mercantile, industrial, and financial connections." The committee thus likely considered groups of counties that voted similarly as inseparable blocs to be fit together to form Federal Reserve districts of sufficient size to support a Reserve Bank. Whereas the Boston, New York, Philadelphia, and Chicago districts were formed largely by counties that favored only those cities, other districts were formed by combining groups of counties that had voted for different cities so as to amass the minimum

\footnotetext{
${ }^{24}$ In calculating these percentages, counties with the same number of votes for two different cities (i.e., a tie vote) are included in the county total and counted as non-matches.
} 
capital to establish a Reserve Bank. For example, Willis (1923, pp. 587-88) claims that the RBOC included the southeastern part of Louisiana in the Atlanta district to ensure that the Federal Reserve Bank of Atlanta had the minimum $\$ 4$ million capital, even though banks in that region had mostly voted for New Orleans and had closer banking and commercial ties to St. Louis. A branch of the Atlanta Bank was opened in New Orleans shortly after the system was established.

The correspondence between Federal Reserve district boundaries and county-aggregated vote totals is shown in Figure 2, which maps district boundaries (as set in 1914) and the results of the RBOC survey. The maps show the district borders set by the RBOC (Panel A), the counties won by the city chosen for each district's Reserve Bank (Panel B), and the counties won by each district's Reserve Bank and branch cities (Panel C). ${ }^{25}$ Unshaded counties had no recorded votes (either because the county had no national banks, none returned a ballot, or their votes were not transcribed) or voted for a city that was not chosen for a Reserve Bank or branch.

The maps show that district boundaries generally matched voting patterns. Some divisions are clear and match geography. For instance, support for Philadelphia ran to the southern border of Pennsylvania and thus matches the district boundary. However, voting patterns also explains some of the less straight-forward geographic divisions between districts. For instance, nearly all counties in Iowa voted for and were assigned to the Chicago district, including those that are closer to either Minneapolis or Kansas City. Moreover, nearly all of the mid-state district splits are also reflected in the voting data. For instance, the district boundary

\footnotetext{
${ }^{25}$ In Panel C, we shade with a single color all of the counties whose banks voted for a given Reserve Bank city or any of the branches that were established in the district. For example, we shade in blue all counties won by Cleveland, Cincinnati, and Pittsburgh. Counties shaded in black are those where two or more cities received equal numbers of votes. However, we add the first-place votes for Reserve and branch cities before determining the outcome of each county-level vote. This eliminates any potential ties between Reserve Bank and branch cities. For instance, we would assign two votes for Cleveland for any county that supplied one vote for Cleveland and one for Cincinnati.
} 
lines in Illinois and Pennsylvania largely match the voting blocs of Chicago/St. Louis and Philadelphia/Pittsburgh.

Not all district borders were set precisely with voting blocs. For example, the RBOC assigned several counties in Wisconsin and the upper peninsula of Michigan to the Minneapolis district, despite having been won by Chicago. Similarly, the committee assigned a handful of counties in Arizona and New Mexico to the Dallas district that had been won by Kansas City or San Francisco. Still, for the most part, the district boundaries correspond closely with the voting patterns observed in the county-level data.

In addition to their explanatory power for the initial district boundaries, banker preferences also help explain the few boundary changes made after the Fed was established. The Federal Reserve Board adjusted district boundaries at the request of member banks. Banks were probably more likely to request a change if they had been assigned to a district that did not include their preferred Reserve Bank city. For example, banks in central and eastern Wisconsin that voted for Chicago yet were placed in the Minneapolis district quickly petitioned to be moved to the Chicago district, arguing that the RBOC had acted "Without due regard to the convenience and customary course of business" (Weed 1914, p. 1). Banks in western Connecticut and northern New Jersey asked to be moved to the New York district for similar reasons.

Table 5 examines the relationship between boundary changes and voting patterns. The Federal Reserve Board moved 84 counties with recorded votes from their originally-assigned districts to other districts. ${ }^{26}$ Of those, 70 percent were moved to a district that included the Reserve Bank city or a branch city that had won the county's vote in the RBOC survey. Only 9 counties (10.7 percent) were moved out of a district that included the city that won the county's

\footnotetext{
26 Including counties with no recorded votes, the Board moved 121 counties from their original district between 1914 and 2013.
} 
vote, and 6 percent were moved between districts in which neither included the city that won the county's vote. ${ }^{27}$ The remaining 13.1 percent of counties moved had split votes, usually between cities in both the original and new districts. For instance, single votes were recorded for both St. Louis and Kansas City in Johnston County, Missouri. The county was initially placed in the St. Louis district but later moved to the Kansas City district.

\section{The Relative Importance of First-Choice Votes and Distance for District Boundaries}

It seems clear that the RBOC relied heavily, but perhaps not exclusively, on the results of its survey of national banks in selecting Reserve Bank cities and setting district lines. The Committee also claimed that it considered "the geographical situation of the district, transportation lines, and the facilities for speedy communication between the Federal Reserve bank and all portions of the district." Accordingly, the RBOC may have preferred to limit the distance between Reserve Bank offices and their members in an effort to ensure timely delivery of services and access to the Fed's discount window. We use a multivariate regression model to examine the relative importance of distance and banker preferences. Because there are many possible outcomes (i.e., one for each Fed district), we look at the choice around each district separately. The dependent variable ( District $_{i}$ ) is a dummy variable that takes the value 1 when County $i$ was placed in the specified district and 0 otherwise. This approach generates 12 regressions of the form:

$$
\text { District }_{i}=a+\beta_{1} \text { VoteCorrect }_{i}+\beta_{2} \text { DistanceCorrect }_{i}+e_{i}
$$

where VoteCorrect $t_{i}$ is a dummy variable that takes the value 1 if a plurality of banks in County $i$ voted for the Reserve Bank (or a branch) city of the county's district, and DistanceCorrect $_{i}$ is a dummy variable that takes the value 1 if County $i$ was nearer to its district's Reserve Bank (or a

\footnotetext{
${ }^{27}$ Two other counties were moved to districts that included a city won by the county that was neither a Reserve Bank nor a branch office city.
} 
branch) city than to any other district's Reserve Bank or branch cities. ${ }^{28}$ Knowing that both variables are likely important, the model essentially sets up a horse race between the two.

Although we could use a sample containing all U.S. counties for each regression, the RBOC's stated goals would not have allowed it to place, say, a county on the West Coast in a district in the Northeast. We thus limit the sample for each district regression to counties that were in the specified district or a neighboring district. The approach minimizes the amount of extraneous information and allows us to study the margins that would have concerned the RBOC.

We estimate Equation (3) in two ways for each district. We first consider only the distance to and votes for Reserve Bank cities, and then we consider the distance to and votes for Reserve Bank and branch cities. Table 6 reports the results. When considering Reserve Bank cities only, voting is more important than distance for the New York, Philadelphia, Chicago, and Minneapolis districts, whereas distance is more important for the Boston, Cleveland, Richmond, Atlanta, Kansas City, Dallas, and San Francisco districts. The coefficients for voting and distance are not statistically different from one another for the St Louis district. When branch cities are included, the county-level vote totals are almost always more important than distance for explaining whether or not a given county is included in a particular district. The coefficient on the vote dummy is larger than the coefficient on the distance dummy for 10 of the 12 districts. The coefficients on voting and distance are not statistically different for the Dallas district, and the coefficient on the distance dummy is larger for the Boston district. ${ }^{29}$

\footnotetext{
${ }^{28}$ We calculate each county's GPS coordinates as an average of the locations in the county.

${ }^{29}$ Distance likely matters more than votes for Boston because many counties in western Connecticut, Massachusetts, and Vermont that favored New York City were instead assigned to the Boston district. Further, if we redefine VoteCorrect $_{i}$ to equal 1 if a plurality of banks in County $i$ voted for any city in its district, the coefficient on the variable increases and the coefficient on distance decreases for most districts, and the effect of voting becomes much larger than distance for the Atlanta district.
} 
The regression results tell a story. County-level voting patterns were clearly important for districts where a single city had sufficiently wide support to establish a Bank with at least the minimum required capitalization. Therefore, when voting for branch cities is excluded, distance appears relatively more important for determining the boundaries of districts where no single city received enough support for a Bank. However, this ignores the possibility that the RBOC (whose members would be directly involved in authorizing branches as members of the Federal Reserve Board) foresaw branches as likely in cities that anchored large blocs of counties that were joined to form districts. Because branch offices were subsequently opened in many of the cities that had received substantial support for a Reserve Bank, the results of the RBOC survey of national banks dominate distance for nearly all districts when we compare the importance of votes for Reserve Bank and branch cities with distance to the nearest city with a Reserve Bank or branch.

The results beg yet another question: What factors led the RBOC to go against the votes of national banks? Of 1,874 counties with at least one recorded vote, 292 were placed in a district that did not include the city favored by a plurality of the county's national banks (59 of those counties were later moved into their preferred district). Since banks in many of the mismatched counties had voted for a city that was neither chosen for a Reserve Bank nor became a branch location, we focus on the 1,126 counties whose banks voted for one the 12 cities chosen for a Reserve Bank. Of those, 141 were placed in a district that did not include the city favored by the county's banks in 1914, and 41 of those counties were later moved into their preferred district.

We estimate the following regression:

$$
\text { AgainstVote }_{i}=a+\beta_{1} \text { DistancetoVote }_{i}+\beta_{2} \text { DistancetoDistrict }_{i}+\beta_{4} Z_{i}+d_{i}+e_{i}
$$


where AgainstVote $_{i}$ is a dummy that takes the value 1 if County $i$ was placed in a district other than the one favored by the banks in that county. ${ }^{30}$ DistancetoVote $_{i}$ is the logarithm of the distance from County $i$ to the city that won the county's vote, and DistancetoDistrict ${ }_{i}$ is the logarithm of the distance from County $i$ to the Reserve Bank city of the district to which the county was assigned. The two distances allow us to determine whether the RBOC might have been more inclined to go against the preferences of a county's banks the further the county was from the county's favored city and the closer it was to the Reserve Bank city of another district. $Z_{i}$ is a vector that includes County $i$ 's population, logarithm of national bank capital, and logarithm of state bank capital. The RBOC might have been more likely to make unpopular choices for rural counties with low population or little bank capital, and therefore with little incentive or power to contest a decision. Finally, district dummies capture whether certain districts were more or less likely to include counties whose banks favored a different Reserve Bank city.

The results reported in Table 7 indicate that counties were more likely to be placed outside their preferred district, the farther they were from the city favored by the county's banks and the closer they were to a Reserve Bank or branch city in its assigned district. The coefficient on population is significant and positive, indicating that the $\mathrm{RBOC}$ was more likely to place larger counties outside the district preferred by its banks, perhaps in an effort to make districts more equal in terms of population.

The coefficients on the district dummies in column (2) indicate the extent to which there were district-specific differences in the assignment of counties to other than their preferred

\footnotetext{
${ }^{30} \mathrm{We}$ drop counties with tie votes from the sample because the tie often was between a city in the county's original district and one in the district to which it was later moved.
} 
districts. ${ }^{31}$ For example, the negative coefficient for the New York district indicates that, relative to the omitted Boston district, banks in counties assigned to the New York district were significantly less likely to have preferred being placed in a different district.

\section{Banker Preferences and Correspondent Relationships}

The previous sections have provided considerable evidence that the results of the RBOC survey of national banks strongly influenced the selection of cities for Federal Reserve Banks and branches, and the delineation of district boundaries. However, what did the survey results represent? Testing the hypothesis suggested by Odell and Weiman (1998), we examine whether voting patterns reflected established correspondent relationships.

Many bankers expressed their preferences in hearings before the RBOC. Bankers often cited their existing business relationships and markets for why they favored a particular city for a Reserve Bank. For example, a Hopkinsville, Kentucky, banker testified that Louisville was his first choice for a Reserve Bank because "we are very intimately associated with them in a business way, and in a social way too. Next to Louisville, our choice is St. Louis.... The majority of the national bankers in eastern Kentucky have accounts in St. Louis. It would be very much to the advantage of our community if we could not get in the Louisville district to come to St. Louis" (RBOC 1914b, pp. 1760-1761).

Some bankers did not express a preference for a particular city, but instead emphasized the importance of keeping their market area within a single Federal Reserve district. For example, an El Paso, Texas banker and president of the local clearinghouse testified: "El Paso comes before your Honorable Committee, not as an applicant for a regional Reserve Bank... but simply asking that our territory be kept intact. By our territory, I mean that part which we

\footnotetext{
${ }^{31}$ When including dummies for a county's vote outcome rather the district outcome, the results are similar albeit with the opposite sign.
} 
consider the trade territory of El Paso..." The banker went on to define that territory as encompassing southern New Mexico, southern Arizona, and Texas west of the Pecos River. When asked whether this region would be better served by a Reserve Bank in San Francisco, Denver, or Kansas City, the banker responded, "I do not think there is very much difference .... I should say that any of those three points would serve this district equally well." (RBOC 1914c, pp. 3101-3103)

As the quote from the Hopkinsville banker makes clear, established correspondent relationships were an important consideration for placement of Reserve Banks and district boundaries. Banks sought correspondents in cities where they had frequent need for payments services, and cities with good transportation services at the center of major agricultural or commercial areas often became significant correspondent banking centers (Duncan and Lieberson, 1970; Odell and Weiman, 1998). Those cities were likely candidates for Reserve Banks and branches because they met several of the RBOC's stated criteria for selecting Reserve Bank cities, including extensive transportation and commercial ties within their regions.

We recorded the locations of all correspondents listed for every national bank in the January 1913 Rand McNally Bankers Directory. Table 8 reports the number of correspondent links to every city with at least 10 links. For example, national banks from throughout the United States reported 7,119 correspondent relationships with banks located in New York City—more than twice as many links than to any other city. Of the 7,454 national banks listed in the directory, approximately 84 percent reported at least one New York City correspondent, and some banks had multiple correspondents (which is why the number of links to New York City exceeds 84 percent of 7,454). 
As the nation's financial capital, as well as a major manufacturing and commercial center, New York City was at the center of the interbank market and most banks found it advantageous to have at least one New York City correspondent. Chicago was the nation's second largest city and commercial center, and its banks also attracted correspondent business from throughout the country, with some 35 percent of all national banks having a Chicago correspondent.

Figure 3 provides examples of the density and reach of correspondent banking links to various cities. Whereas New York City and Chicago attracted business from throughout the nation, Boston and Philadelphia attracted most of their correspondent business from banks in the Northeast, though many banks in major cities throughout the country also had correspondents in Boston or Philadelphia. Minneapolis/St Paul and San Francisco were almost entirely regional correspondent centers with only a few links to banks in other regions. Finally, Atlanta and Dallas drew nearly all of their correspondent business from within their own states, with no links from outside their immediate regions.

Most of the cities chosen for Reserve Banks were already national or major regional correspondent banking centers, and all received substantial numbers of first-choice votes in the RBOC survey of national banks. Still, the RBOC passed over a few cities with significant correspondent banking links that had also received large numbers of votes. For example, as Figure 4 shows, Baltimore had more correspondent links and drew business from a larger geographic area than did Richmond, and both Pittsburgh and Cincinnati drew from larger areas than did Cleveland. ${ }^{32}$ Richmond, however, received more first-choice votes than Baltimore and won substantially more counties. By contrast, Cleveland received fewer votes, won fewer

\footnotetext{
${ }^{32}$ Citizens of Baltimore were so incensed at being passed over that they petitioned the Federal Reserve Board to move the Reserve Bank of the $5^{\text {th }}$ Federal Reserve District from Richmond to Baltimore (which the Board turned down) (https://fraser.stlouisfed.org/docs/historical/nara/nara_rg082_e02_b2661_01.pdf).
} 
counties, and had fewer correspondent links than either Pittsburgh or Cincinnati, suggesting that its selection was based on other criteria. ${ }^{33}$

Next, we investigate how closely the county-aggregated votes align with established correspondent connections. For each city that received a plurality of votes in at least one county outside the city's home county, Table 9 reports 1) the total number of non-home counties won; 2) the percentage of counties won where the city also had the largest share of correspondent links; 3) the percentage of counties won where the city and another city had equal numbers of correspondent links (and no other city had more links); and 4) the percentage of counties won where the city had fewer correspondent links than another city. ${ }^{34}$ For example, 24.2 percent of the counties won by Atlanta had more correspondent links to Atlanta than to any other votereceiving cities, and 27.4 percent of the counties won by Atlanta had the same number of links to Atlanta as to another city (and fewer links to all other cities). By contrast, 48.4 of the counties won by Atlanta had more correspondent links to other cities. Across all cities, 64.9 percent of the counties won had more correspondent links to the given city than to any other cities, and another 18.2 percent of counties won had the same number of correspondent links to the city and another city (and fewer links to all other cities). ${ }^{35}$

The final column of Table 9 reports the percentage of counties won by each city that were closer in distance to the city than to any other city that received votes. For example, 46.8 percent of the 63 counties won by Atlanta (excluding its home county) are closer to Atlanta than to any other city that received votes. In general, voting patterns align more closely with correspondent

\footnotetext{
${ }^{33}$ The RBOC (1914a, p. 24) noted that Cleveland was one of the nation's six largest cities and that the "geographical situation and all other considerations fully justified" the placement of a Reserve Bank in all of those cities. Otherwise, the committee did not comment on the selection of Cleveland, rather than Pittsburgh or Cincinnati.

${ }^{34}$ Given their legal status as central reserve cities, we drop correspondent links to New York City, Chicago, and St Louis when calculating the percentages for all other cities, and drop New York City correspondents when calculating the percentages for Chicago and St Louis.

${ }^{35}$ Many of the counties with equal numbers of correspondent links to two cities had only one bank.
} 
links than with distance, especially among cities that won more than 15 counties. For example, only 25 percent of counties won by Kansas City are closer to Kansas City than to another city that received votes. However, 87 percent of the 150 counties won by Kansas City had more correspondent links to Kansas City than to any other city. By contrast, voting patterns align more closely with distance than correspondent links primarily for cities that won few counties. For example, only one of the nine counties won by Charlotte had more correspondent links to Charlotte than to any other city, but all were closer to Charlotte than to any other city that received votes. In general, the correspondent links of national banks were somewhat more concentrated among the larger financial centers than were their votes, though clearly voting patterns followed established correspondent relationships to a large degree.

\section{Empirical Model of First-Choice Votes}

Whereas voting patterns generally mirrored preexisting correspondent linkages, it could be that those links, and hence votes, simply reflected a city's size and financial depth. Thus, we examine the effect of correspondent links on the total number of votes and total number of counties won by cities while controlling for other factors, such as whether a city was a designated reserve or central reserve city under the National Banking Act. We estimate city-level regressions similar to Equation (2), where the dependent variable $\left(\right.$ Votes $\left._{i}\right)$ is the logarithm of either the number of first-choice votes or the number of counties won by City $i$. The sample contains all cities with urban populations above 30,000 regardless of whether they were subsequently chosen as a Reserve Bank or branch city. The model is:

$$
\text { Votes }_{i}=a+\beta_{1} \text { Correspondents }_{i}+\beta_{2} X_{i}+\beta_{3} \text { ReserveCity }_{i}+s_{i}+e_{i}
$$

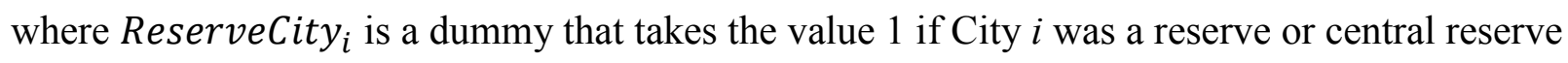
city, $s_{i}$ is a vector of state dummies, and the rest of the variables retain their aforementioned 
definitions. Because New York City and Chicago were much larger, received many more votes, and had many more correspondent links than other cities, we estimate the specification both with and without those two cities to ensure they are not driving the results.

Table 10 displays the estimation results for Equation (5). In all four specifications, the effect of correspondent links is large and statistically significant. A doubling of the number of correspondent links would increase a city's expected number of votes by 44 to 69 percent and number of counties won by 30 to 52 percent. The effect of correspondent links is stronger when New York City and Chicago are excluded. Encouraged by statutory reserve requirements and the advantages of the correspondent network's payment services and interest income, most national banks had at least one New York City or Chicago correspondent. However, most national banks also had correspondents in regional centers that were closer to home, and likely would have preferred those cities for the location of their Reserve Bank. Indeed, excluding links to New York City and Chicago, the main correspondent location of national banks in over 75 percent of counties was within 200 miles (most of the counties with larger distances to their principal correspondent are in the West where counties and distances between cities are larger). Thus, the relationship between number of votes received and number of correspondent links is closer for most cities than it is for New York City and Chicago.

The estimation results indicate that both the number of votes and the number of counties won were also influenced by city population in 1910 and the percentage change in population over the prior decade. The results are strongest for the percentage change in population, however, as the coefficient on 1910 population is smaller and not statistically significant in regressions that exclude New York City and Chicago. A large increase in population was perhaps a reflection of expanding economic activity that attracted votes from banks hoping to 
find new business opportunities by becoming affiliated with a Reserve Bank in a growing city. Similarly, the coefficient on national bank capital is smaller (and is much less close to being statistically significant) in both sets of regressions when New York City and Chicago are excluded. At the margin, New York City and Chicago received more votes because of the size of their banking markets. After controlling for correspondent links and other local characteristics, the amount of local banking capital did not influence the number of votes that most cities received. We also find a positive impact of being an urban commercial and transportation center, as reflected in Bensel's (1984) "urban center" designation, on the number of votes received. However, the negative coefficients on the number of businesses in the city listed by Bradstreet are puzzling and perhaps suggest that the type rather than number of businesses influenced preferences.

Conclusion

The Federal Reserve System was established in 1914 to supplant the web of interbank connections and correspondent relationships that commercial banks relied upon for making payments, obtaining seasonal liquidity and investing surplus funds. Dissatisfaction with "seasonal stringency" in money markets, frequent banking panics, and the concentration of the nation's bank reserves in a few large cities (especially New York City) gave impetus to create the Federal Reserve System. The Federal Reserve Act called for the establishment of as many as 12 districts, each served by a Federal Reserve Bank (with the possibility of branch offices), and charged a Reserve Bank Organization Committee with determining the number of districts and their territories, and the location of a Reserve Bank within each district. After holding hearings in 18 cities and canvassing national banks, the RBOC announced its decisions in April 1914. 
The RBOC's decisions have been the source of much criticism. Early on, critics charged the RBOC with passing over important banking centers, such as Baltimore and New Orleans, while locating Reserve Banks in smaller, less established cities, such as Richmond, Atlanta, and Dallas. Political considerations were widely viewed as the impetus for the placement of two Reserve Banks in Missouri, and influential on the selections of Richmond, Atlanta and Cleveland.

Our research finds that the RBOC constructed the Federal Reserve System on the foundation of the existing interbank network. Expanding on previous studies, we confirm that the selection of cities for Reserve Banks and the delineation of district boundaries were driven primarily by the preferences of national banks as reflected in a survey conducted by the RBOC. Those preferences, in turn, largely mirrored preexisting correspondent relationships. Specifically, banks typically voted for cities where they already had correspondent relationships. Banker preferences (and thus correspondent relationships) were so important that they continued to affect the System's structure by influencing the selection of branch cities and changes made to district boundaries after the Fed was established.

The Fed's structure turned out to be consequential for the performance of the System and the cities and regions where Reserve Banks were located. As changes to the System's structure are again being contemplated, it is important to understand both the rationale and the process by which that structure was established because if the System is to be remade, it is important to know how the pieces were put together in the first place. 


\section{$\underline{\text { References }}$}

Angrist, Joshua and Jörn-Steffen Pischke (2009) Mostly Harmless Econometrics: An Empiricist's Companion. Princeton: Princeton University Press

Bensel, Richard. (1984). Sectionalism and American Political Development, 1880-1980. Madison: University of Wisconsin Press.

Binder, Sarah and Mark Spindel. (2013). "Monetary Politics: Origins of the Federal Reserve." Studies in American Political Development 27: 1-13.

Bordo, Michael D. (2015). "Some Historical Reflections on the Governance of the Fed." Presented at a Hoover Institution conference on "Central Bank Governance and Oversight Reform: A Policy Conference,” May 21, 2015.

Bordo, Michael D. and David C. Wheelock. (2013). "The Promise and Performance of the Federal Reserve as Lender of Last Resort 1914-1933." In The Origins, History, and Future of the Federal Reserve: A Return to Jekyll Island, edited by Michael D. Bordo and William Roberds, Cambridge University Press, 59-98.

Bureau of the Census, 1910. Telephones: 1907. GPO, Washington, DC.

Calomiris, Charles and Gary Gorton. (1991) "The origins of banking panics: models, facts, and bank regulation." In Financial markets and financial crises, edited by R. Glenn Hubbard. Chicago: University of Chicago Press, pp. 109-174.

Carlson, Mark and Kris J Mitchener. (2006). "Branch banking, bank competition, and financial stability." Journal of Money, Credit, and Banking 38: 1293-1328.

Carlson, Mark and David C. Wheelock. (2015). "Interbank Markets and Banking Crises: New Evidence on the Establishment and Impact of the Federal Reserve." Unpublished Working Paper. 
Dearie, John. (2015). "The U.S. Needs Two More Federal Reserve Banks," The Wall Street Journal, March 16, 2015, p. A11.

Duncan, Beverly and Stanley Lieberson. (1970). Metropolis and Region in Transition. Beverly Hills, CA: Sage Publications.

Federal Reserve Bank of St Louis. (2014). 100 Years of Service 1914-2014.

(https://www.stlouisfed.org/ /media/Files/PDFs/publications/pub_assets/pdf/ar/2013/201 3_AnnualReport.pdf)

Fisher, Richard. (2015). "Suggestions After a Decade at the Fed." Remarks before the Economic Club of New York. New York City: February 11, 2015. (http://www.dallasfed.org/news/speeches/fisher/2015/fs150210.cfm)

Hackley, Howard H. (1973). Lending Functions of the Federal Reserve Banks: A History. Washington, D.C.: Board of Governors of the Federal Reserve System.

Haines, Michael R. (2005). Historical, Demographic, Economic, and Social Data: The United States, 1790-2000. ICPSR Study 2896. Ann Arbor, MI: Inter-university Consortium for Political and Social Research.

Hammes, David (2001). "Locating Federal Reserve Districts and Headquarters Cities." The Region, Federal Reserve Bank of Minneapolis, September 1, 2001.

Interstate Commerce Commission, (1914). Twenty-Sixth Annual Report on the Statistics of the Railways of the United States for the Year Ended June 30, 1913. GPO, Washington, DC. James, John A. (1978). Money and Capital Markets in Postbellum America. Princeton: Princeton University Press. 
James, John A., and David F. Weiman. (2010). "From drafts to checks: the evolution of correspondent banking networks and the formation of the modern US payments system, 1850-1914." Journal of Money, Credit and Banking 42: 237-265.

Kemmerer, Edwin. (1910). Seasonal Variations in the Relative Demand for Money and Capital in the United States. National Monetary Commission, U.S. Government Printing Office: Washington DC.

McAvoy, Michael. (2004). "Bankers Preferences and Locating Federal Reserve District Bank Locations." Essays in Economic \& Business History 22: 143-169.

McAvoy, Michael. (2006). "How were the Federal Reserve Bank locations selected?" Explorations in Economic History 43: 505-526.

Meltzer, Allan H. (2003). A History of the Federal Reserve, Volume 1: 1913-1951. Chicago: University of Chicago Press.

National Monetary Commission. (1911). Suggested Plan for Monetary Legislation: Submitted to the National Monetary Commission. https://fraser.stlouisfed.org/title/?id=664, accessed on May 6, 2015.

Odell, Kerry A., and David F. Weiman. (1998). "Metropolitan development, regional financial centers, and the founding of the Fed in the Lower South." The Journal of Economic History 58: 103-125.

Rand McNally Bankers' Directory $(1903,1913)$. Chicago: Rand McNally.

Reserve Bank Organization Committee. (1914a). Decision of the Reserve Bank Organization Committee Determining the Federal Reserve Districts and the Location of Federal Reserve Banks under the Federal Reserve Act Approved December 23, 1913. [https://fraser.stlouisfed.org/title/?id=603\#scribd-open] 
Reserve Bank Organization Committee. (1914b). "Federal Reserve District Divisions and Location of Federal Reserve Banks and Head Offices.” Hearings of the Reserve Bank Organization Committee, St. Louis, Missouri, January 21-22, 1914. (https://fraser.stlouisfed.org/docs/historical/federal\%20reserve\%20history/rboc/rbocheari ngs_19140122_stlouis.pdf)

Reserve Bank Organization Committee. (1914c). "Federal Reserve District Divisions and Locations of Federal Reserve Banks and Head Offices.” Hearings of the Reserve Bank Organization Committee, El Paso, Texas, February 7, 1914. (https://fraser.stlouisfed.org/docs/historical/federal\%20reserve\%20history/rboc/rbocheari ngs_19140207_elpaso.pdf).

Richardson, Gary, and William Troost. (2009). "Monetary Intervention Mitigated Banking Panics during the Great Depression: Quasi-Experimental Evidence from a Federal Reserve District Border, 1929-1933." Journal of Political Economy 117: 1031-73. Sprague, O.M.W. (1910). History of Crises under the National Banking System. Washington, DC: National Monetary Commission, Senate Document 538, 61st Congress, $2 \mathrm{~d}$ Session. Tippets, Charles (1929). State Banks and the Federal Reserve System. New York: D. Van Nostrand Company, Inc.

Weed, Henry. (1914). Abstract of Testimony Before Organization Committee and Brief and Argument on Behalf of Petitioners. Records of the Federal Reserve System, 1878-1996, Record Group 82. United States. National Archives and Records Administration. Wicker, Elmus. (2000). Banking Panics of the Gilded Age. Cambridge, UK: Cambridge University Press. 
Willis, H. Parker. (1923). The Federal Reserve System, Legislation, Organization and Operation. New York: Ronald Press.

Woolridge, Jeffrey (2010). Econometric Analysis of Cross Section and Panel Data Second Edition. Cambridge: MIT Press.

Ziebarth, Nicolas L. (2013). "Identifying the Effects of Bank Failures from a Natural Experiment in Mississippi during the Great Depression." American Economic Journal: Macroeconomics 5: 81-101. 
Table 1: First Choice Votes By City Receiving Votes

Chicago

New York/Brooklyn

Minneapolis/St Paul

Philadelphia

Kansas City

Pittsburgh

Dallas/Ft Worth

St Louis

Cincinnati

Boston

San Francisco

Omaha

Richmond

Baltimore

Denver

Atlanta

Louisville

Cleveland

Houston

Portland

Birmingham

New Orleans

Seattle

Columbus

Salt Lake City

Spokane

Columbia

Washington DC

Los Angeles

Nashville

Savannah

Detroit

Lincoln

Charlotte

Indianapolis

Des Moines

Memphis

Jacksonville

Buffalo

Milwaukee

Chattanooga

Albany

Sioux City

Reserve

Reserve

Requested
Reserve
Bank

Branch

Before

Bank

Yes

Yes

Yes

Yes

Yes

Yes

Yes

Yes

Yes

Yes

Yes

Yes

Yes

Yes

Yes

Yes

Yes

Yes

Yes

Yes

Yes

Yes

Yes

Yes

Yes

Yes

Yes

Yes

No

No

Yes

No

Yes

Yes

No

No

Yes

No

No

No

Yes

No

No

Branch

Branch

Branch

Branch

Branch

\begin{tabular}{c}
$\begin{array}{c}\text { Total First } \\
\text { Choice } \\
\text { Votes } \\
\text { (Official) }\end{array}$ \\
\hline 906 \\
673 \\
508 \\
508 \\
506 \\
355 \\
321 \\
299 \\
299 \\
290
\end{tabular}

Total

Votes

(From

County

Maps)

389

355

304

301

199

183

194

181

177

144

134

95

83

70

81

59

71

67

45

41

28

29

18

16

23

18

10

17

21

16

16

11

14

14

10

24

23

19

19

17

16

14

14

13

11

10

10

Note: Table contains all cities that received at least 10 first choice votes. The censoring leaves off four cities that eventually became branches: El Paso, Helena, Little Rock, and Oklahoma City. See Table 2 for data sources. 


\section{Table 2: Variables Included in Regression Analysis}

Bank Preferences

$\mathrm{Ln}$ (\# of First Choice Votes)

$\operatorname{Ln}$ (\# of Counties Won)

Ln(\# of Corr. Links) in 1913

Economic, Demographic, and Locational Variables

Population in 1910

\%Change in Population 1900-1910

\%Change in National Bank Capital 1903-1913

Ln(National Bank Capital) in 1913

Ln(State Bank Capital) in 1913

Ln(City's Bradstreets Names in 1914)

Urban Center Dummy

Ln(Railroads Per Person in 1910)

Ln(Telephones Per Person in 1907)

Ln(Distance to Reserve City)

Political Variables

\% Democrats in Congress in 1914

\% Republican Votes on Fed Reserve Act

\# of Representatives on Congressional Banking Committees in 1914

\section{Description and Corresponding Hypothesis}

Total Number of First Place Votes Received By City from the final data Captures the importance of national bank preferences.

Total Number of Counties Where City Received Most First Choice

Votes from the county-level maps. Captures the importance of national bank preferences.

Number of Unique National Bank Correspondent Links To City.

Captures the importance of pre-existing bank relationships.

City Population in 1910. Captures the extent that large cities were preferred.

Percent Change in Population 1900 to 1910. Captures the extent that growing cities were preferred.

Percent Change in National Bank Capital 1903 to 1913. Captures the extent that growing financial centers were preferred.

National Bank Capital in City in 1913. Captures the extent that large financial centers were preferred.

State Bank Capital in City in 1913. Captures the extent that large financial centers were preferred.

Number of businesses listed in Bradstreet's credit files in 1914. Captures the extent that size of a city's commercial activity was important.

Whether Bensel determined the city to be the urban center of a trade area in 1895. All urban centers take a value of "1". Captures the extent that cities with largest population and transportation networks of surrounding area were preferred.

Number of railroad miles per person in state in 1910. Captures need for

Reserve Banks to have good transportation throughout the district.

Number of telephones and exchanges per person in state in 1907.

Captures need for Reserve Banks to have good communication

throughout the district.

Logarithm of geographic distance between the city and the Reserve City in its district. Captures potential need for branches that were far away from Reserve Bank.

Fraction of State's Congressmen that were Democrats in 1914. Captures potential division of spoils amongst winning political party.

Fraction of State's non-Democrat Representatives that voted for Federal

Reserve Act in 1913. Captures potential desire to draw Progressive

Republicans into the Democratic fold for the 1916 elections

Whether state had a representative on House or Senate Banking

Committee. Captures the potential that political favors were made to obtain approval through the Committees.

\section{Source}

RBOC (1914b)

National Archive Records of the Federal Reserve System

Rand McNally Bankers Directory (1913)

Haines (2005)

Haines (2005)

Comptroller of the Currency (1903, 1913)

Comptroller of the Currency (1913)

Rand McNally Bankers Directory (1913) and various state records

National Archive Records of the Federal Reserve System

Bensel (1984)

Interstate Commerce Commission

Bureau of the Census (1910)

Obtained directly from GPS coordinates

http://history.house.gov/People/Search Congressional Record - House (1913, p. 1464)

McAvoy (2006, Table 4).

Notes: Table contains a list of the variables used in the city-level regression as well a description and source. 
Table 3: Linear Model of Determinants of Reserve Bank and Branch Cities

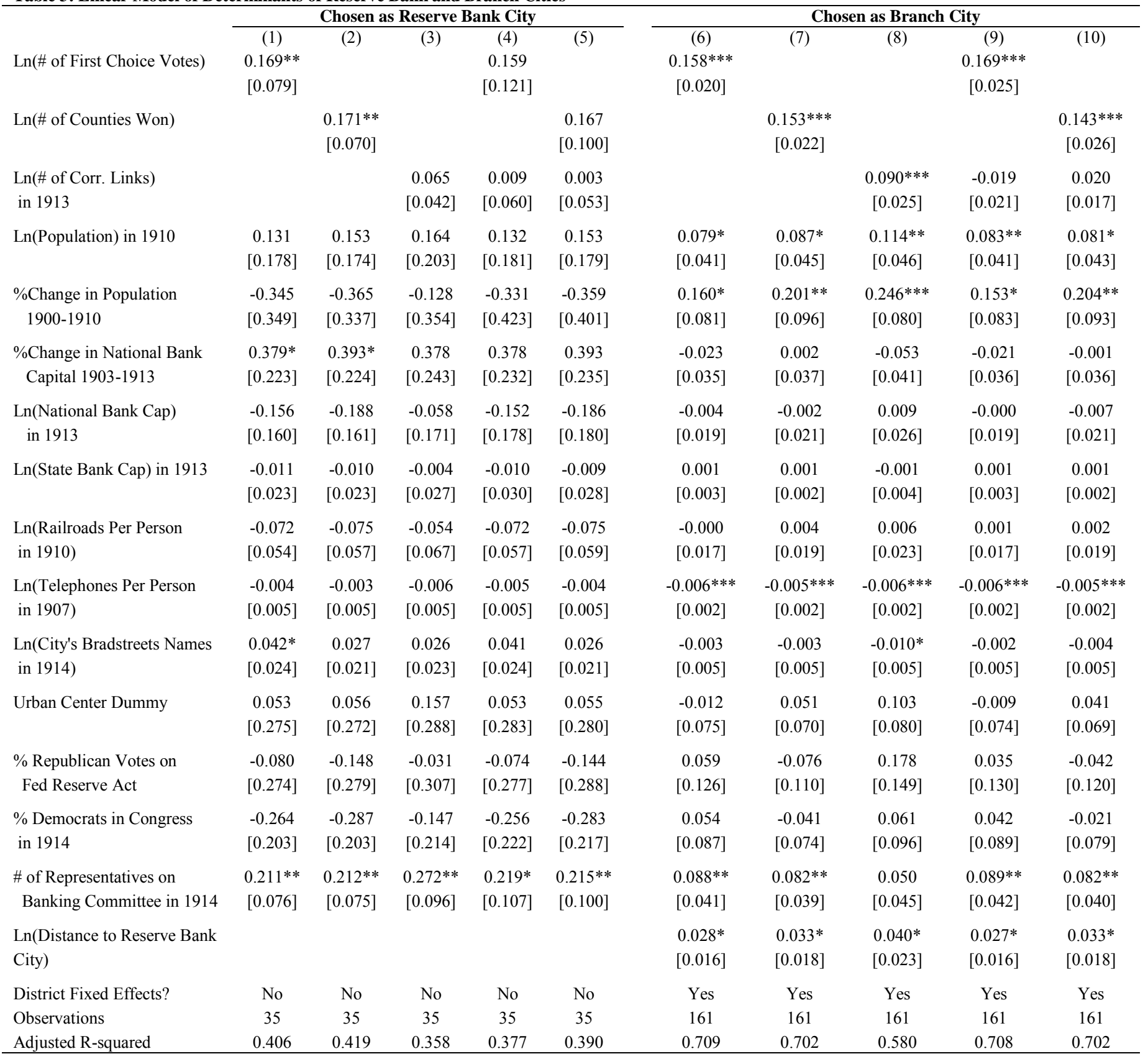

Notes: The table presents the results of a linear probability model where the dependent variable is listed at the top of each column. The Reserve Bank City regressions include only cities that requested a Reserve Bank, whereas as the Branch City regressions include all cities with an urban population above 30,000 in 1910 that were not chosen for a Reserve Bank. Huber-White standard errors are provided in brackets. * denotes significance at $10 \%$; $* *$ at $5 \%$ level and $* * *$ at $1 \%$ level. 
Table 4: Correspondence of Original District Boundaries and County-Level Voting Patterns

\begin{tabular}{|c|c|c|c|}
\hline & \multirow{2}{*}{$\begin{array}{c}\text { Total Counties } \\
\text { in District with } \\
\text { Votes } \\
\end{array}$} & \multicolumn{2}{|c|}{ \% Counties in District Won by City } \\
\hline & & $\begin{array}{c}\text { Reserve Bank } \\
\text { Cities }\end{array}$ & Branch Cities \\
\hline Atlanta & 163 & $36.8 \%$ & $47.9 \%$ \\
\hline Boston & 61 & $72.1 \%$ & $0.0 \%$ \\
\hline Chicago & 262 & $79.4 \%$ & $5.3 \%$ \\
\hline Cleveland & 136 & $22.1 \%$ & $60.3 \%$ \\
\hline Dallas/Ft Worth & 193 & $48.7 \%$ & $22.3 \%$ \\
\hline Kansas City & 232 & $49.1 \%$ & $44.8 \%$ \\
\hline Minneapolis/St Paul & 219 & $72.6 \%$ & $0.0 \%$ \\
\hline New York & 60 & $100.0 \%$ & $0.0 \%$ \\
\hline Philadelphia & 71 & $70.4 \%$ & $0.0 \%$ \\
\hline Richmond & 164 & $44.5 \%$ & $23.2 \%$ \\
\hline San Francisco & 121 & $38.8 \%$ & $59.5 \%$ \\
\hline St Louis & 165 & $48.5 \%$ & $23.6 \%$ \\
\hline All & 1,847 & $55.2 \%$ & $25.4 \%$ \\
\hline
\end{tabular}

Notes: Counties with no recorded votes are excluded. Counties with the same number of votes for two different cities are included in the county total and counted as non-matches. 
Table 5: Voting Patterns and Changes in District Boundaries (1914-2013)

\begin{tabular}{|c|c|c|c|c|c|c|}
\hline From & To & $\begin{array}{c}\text { Total } \\
\text { Counties } \\
\text { Moved }\end{array}$ & $\begin{array}{c}\text { Original } \\
\text { Reserve } \\
\text { Bank or } \\
\text { Branch } \\
\text { City Won } \\
\text { Vote }\end{array}$ & $\begin{array}{c}\text { New } \\
\text { Reserve } \\
\text { Bank or } \\
\text { Branch } \\
\text { City Won } \\
\text { Vote }\end{array}$ & $\begin{array}{l}\text { Other City } \\
\text { Won Vote }\end{array}$ & $\begin{array}{c}\text { Tie Vote } \\
\text { Between } \\
\text { Cities } \\
\end{array}$ \\
\hline Boston & New York & 1 & $0.0 \%$ & $100.0 \%$ & $0.0 \%$ & $0.0 \%$ \\
\hline Dallas & Atlanta & 6 & $0.0 \%$ & $100.0 \%$ & $0.0 \%$ & $0.0 \%$ \\
\hline Dallas & $\begin{array}{l}\text { Kansas City } \\
\text { San }\end{array}$ & 31 & $16.1 \%$ & $45.2 \%$ & $12.9 \%$ & $25.8 \%$ \\
\hline Dallas & Francisco & 2 & $0.0 \%$ & $50.0 \%$ & $0.0 \%$ & $50.0 \%$ \\
\hline Minneapolis & Chicago & 17 & $5.9 \%$ & $82.4 \%$ & $0.0 \%$ & $11.8 \%$ \\
\hline Philadelphia & New York & 12 & $0.0 \%$ & $100.0 \%$ & $0.0 \%$ & $0.0 \%$ \\
\hline Richmond & Cleveland & 2 & $0.0 \%$ & $100.0 \%$ & $0.0 \%$ & $0.0 \%$ \\
\hline St Louis & Kansas City & 13 & $23.1 \%$ & $69.2 \%$ & $7.7 \%$ & $0.0 \%$ \\
\hline Any & Any & 84 & $10.7 \%$ & $70.2 \%$ & $6.0 \%$ & $13.1 \%$ \\
\hline
\end{tabular}

Notes: Counties with no recorded votes are excluded. When combining votes for all cities in a district, the percent of counties moved that had votes for other cities declines to 10 percent and the percent of counties that voted for the new district rises to 73 percent. 
Table 6: Linear Model of Determinants of Fed District Boundaries

\begin{tabular}{|c|c|c|c|c|c|c|c|c|}
\hline & \multicolumn{8}{|c|}{ Dependent Variable: Whether County Was Placed in Specified District in 1914} \\
\hline & \multicolumn{2}{|c|}{ Boston } & \multicolumn{2}{|c|}{ New York } & \multicolumn{2}{|c|}{ Philadelphia } & \multicolumn{2}{|c|}{ Cleveland } \\
\hline & Reserve & Reserve & Reserve & Reserve & Reserve & Reserve & Reserve & Reserve \\
\hline & Banks & Banks + & Banks & Banks + & Banks & Banks + & Banks & Banks + \\
\hline & Only & Branches & Only & Branches & Only & Branches & Only & Branches \\
\hline Reserve Bank (or Branch City) Was & $0.502 * * *$ & $0.535^{* * *}$ & 0.014 & $0.198 * *$ & $0.137 *$ & 0.133 & $0.682 * * *$ & $0.213 * * *$ \\
\hline Nearest & {$[0.119]$} & {$[0.120]$} & {$[0.095]$} & {$[0.097]$} & {$[0.080]$} & {$[0.082]$} & {$[0.041]$} & {$[0.060]$} \\
\hline Reserve Bank (or Branch City) Won Vote & $\begin{array}{c}0.400 * * * \\
{[0.111]}\end{array}$ & $\begin{array}{c}0.368^{* * *} \\
{[0.112]}\end{array}$ & $\begin{array}{c}0.627 * * * \\
{[0.077]}\end{array}$ & $\begin{array}{c}0.489 * * * \\
{[0.092]}\end{array}$ & $\begin{array}{c}0.826^{* * *} \\
{[0.073]}\end{array}$ & $\begin{array}{c}0.873 * * * \\
{[0.049]}\end{array}$ & $\begin{array}{c}0.297 * * * \\
{[0.040]}\end{array}$ & $\begin{array}{c}0.522 * * * \\
{[0.065]}\end{array}$ \\
\hline Observations & 113 & 113 & 183 & 183 & 414 & 414 & 775 & 775 \\
\hline \multirow[t]{6}{*}{ Adjusted R-squared } & 0.664 & 0.677 & 0.477 & 0.497 & 0.665 & 0.662 & 0.637 & 0.552 \\
\hline & \multicolumn{8}{|c|}{ Dependent Variable: Whether County Was Placed in Specified District in 1914} \\
\hline & \multicolumn{2}{|c|}{ Richmond } & \multicolumn{2}{|c|}{ Atlanta } & \multicolumn{2}{|c|}{ Chicago } & \multicolumn{2}{|c|}{ St Louis } \\
\hline & Reserve & Reserve & Reserve & Reserve & Reserve & Reserve & Reserve & Reserve \\
\hline & Banks & Banks + & Banks & Banks + & Banks & Banks + & Banks & Banks + \\
\hline & Only & Branches & Only & Branches & Only & Branches & Only & Branches \\
\hline Reserve Bank (or Branch City) Was & $0.710 * * *$ & $0.174 * * *$ & $0.654 * * *$ & $0.319 * * *$ & $0.387 * * *$ & $0.190 * * *$ & $0.536 * * *$ & $0.362 * * *$ \\
\hline Nearest & {$[0.044]$} & {$[0.058]$} & {$[0.041]$} & {$[0.055]$} & {$[0.046]$} & {$[0.044]$} & {$[0.045]$} & {$[0.046]$} \\
\hline Reserve Bank (or Branch City) Won Vote & $\begin{array}{c}0.260 * * * \\
{[0.059]}\end{array}$ & $\begin{array}{c}0.739 * * * \\
{[0.051]}\end{array}$ & $\begin{array}{c}0.333 * * * \\
{[0.041]}\end{array}$ & $\begin{array}{c}0.606 * * * \\
{[0.059]}\end{array}$ & $\begin{array}{c}0.555^{* * *} * \\
{[0.038]}\end{array}$ & $\begin{array}{c}0.656^{* * * *} \\
{[0.037]}\end{array}$ & $\begin{array}{c}0.517 * * * \\
{[0.049]}\end{array}$ & $\begin{array}{c}0.506^{* * *} * \\
{[0.049]}\end{array}$ \\
\hline Observations & 515 & 515 & 663 & 663 & 988 & 988 & 1,115 & 1,115 \\
\hline \multirow[t]{5}{*}{ Adjusted R-squared } & 0.567 & 0.587 & 0.697 & 0.782 & 0.590 & 0.583 & 0.554 & 0.587 \\
\hline & \multicolumn{8}{|c|}{ Dependent Variable: Whether County Was Placed in Specified District in 1914} \\
\hline & \multicolumn{2}{|c|}{ Minneapolis } & \multicolumn{2}{|c|}{ Kansas City } & \multicolumn{2}{|c|}{ Dallas } & \multicolumn{2}{|c|}{ San Francisco } \\
\hline & Reserve & Reserve & Reserve & Reserve & Reserve & Reserve & Reserve & Reserve \\
\hline & $\begin{array}{c}\text { Banks } \\
\text { Onlv }\end{array}$ & $\begin{array}{c}\text { Banks + } \\
\text { Branches }\end{array}$ & $\begin{array}{c}\text { Banks } \\
\text { Only }\end{array}$ & $\begin{array}{c}\text { Banks + } \\
\text { Branches }\end{array}$ & $\begin{array}{l}\text { Banks } \\
\text { Only }\end{array}$ & Banks + & $\begin{array}{c}\text { Banks } \\
\text { Only }\end{array}$ & $\begin{array}{c}\text { Banks + } \\
\text { Branches }\end{array}$ \\
\hline Reserve Bank (or Branch City) Was & $0.363^{* * *}$ & $0.288 * * *$ & $0.584 * * *$ & $0.107 * * *$ & $0.658 * * *$ & $0.497 * * *$ & $0.864 * * *$ & $0.147^{*}$ \\
\hline Nearest & {$[0.049]$} & {$[0.057]$} & {$[0.037]$} & {$[0.028]$} & {$[0.040]$} & {$[0.080]$} & {$[0.038]$} & {$[0.079]$} \\
\hline Reserve Bank (or Branch City) Won Vote & $\begin{array}{c}0.603 * * * \\
{[0.049]}\end{array}$ & $\begin{array}{c}0.674 * * * \\
{[0.052]}\end{array}$ & $\begin{array}{c}0.313 * * * \\
{[0.044]}\end{array}$ & $\begin{array}{c}0.727 * * * \\
{[0.036]}\end{array}$ & $\begin{array}{c}0.340 * * * \\
{[0.040]}\end{array}$ & $\begin{array}{c}0.490 * * * \\
{[0.080]}\end{array}$ & $\begin{array}{c}0.114 * * \\
{[0.044]}\end{array}$ & $\begin{array}{c}0.814 * * * \\
{[0.083]}\end{array}$ \\
\hline Observations & 810 & 810 & 1,159 & 1,159 & 844 & 844 & 744 & 744 \\
\hline Adjusted R-squared & 0.721 & 0.680 & 0.574 & 0.736 & 0.771 & 0.716 & 0.891 & 0.934 \\
\hline
\end{tabular}

Notes: The table presents a linear probability model where the dependent variable is a dummy that denotes whether the county was placed in the specified district. The sample includes only counties with recorded votes that were in the district listed or in a neighboring district. Counties with Reserve Bank cities are dropped from the sample. Huber-White standard errors are provided in brackets. ${ }^{*}$ denotes significance at $10 \%$; $* *$ at $5 \%$ level and $* * *$ at $1 \%$ level. 


\begin{tabular}{|c|c|c|}
\hline \multirow[b]{2}{*}{ Ln(Distance to Chosen Reserve Bank) } & \multicolumn{2}{|c|}{$\begin{array}{c}\text { Dependent Variable: } \\
\text { Whether County was Placed } \\
\text { In a non-preferred District }\end{array}$} \\
\hline & $\begin{array}{c}(1) \\
-0.262 * * \\
{[0.106]}\end{array}$ & $\begin{array}{c}(2) \\
-0.235 * * \\
{[0.095]}\end{array}$ \\
\hline Ln(Distance to Winning Vote City) & $\begin{array}{c}0.328 * * * \\
{[0.105]}\end{array}$ & $\begin{array}{c}0.317^{* * *} * \\
{[0.092]}\end{array}$ \\
\hline Ln(State Bank Cap) in 1913 & $\begin{array}{c}-0.008 * \\
{[0.004]}\end{array}$ & $\begin{array}{c}-0.001 \\
{[0.005]}\end{array}$ \\
\hline Ln(National Bank Cap) in 1913 & $\begin{array}{c}-0.011 \\
{[0.014]}\end{array}$ & $\begin{array}{c}-0.020 \\
{[0.014]}\end{array}$ \\
\hline Ln(County Population in 1910) & $\begin{array}{c}0.073 * * * \\
{[0.022]}\end{array}$ & $\begin{array}{c}0.092 * * * \\
{[0.024]}\end{array}$ \\
\hline Placed in New York District & & $\begin{array}{c}-0.267 * * * \\
{[0.067]}\end{array}$ \\
\hline Placed in Philadelphia District & & $\begin{array}{c}0.115 \\
{[0.090]}\end{array}$ \\
\hline Placed in Cleveland District & & $\begin{array}{c}-0.177 * * \\
{[0.070]}\end{array}$ \\
\hline Placed in Richmond District & & $\begin{array}{c}-0.218 * * * \\
{[0.067]}\end{array}$ \\
\hline Placed in Atlanta District & & $\begin{array}{c}-0.157 * * \\
{[0.073]}\end{array}$ \\
\hline Placed in Chicago District & & $\begin{array}{c}-0.218 * * * \\
{[0.071]}\end{array}$ \\
\hline Placed in St Louis District & & $\begin{array}{c}0.035 \\
{[0.082]}\end{array}$ \\
\hline Placed in Minneapolis District & & $\begin{array}{c}-0.013 \\
{[0.077]}\end{array}$ \\
\hline Placed in Kansas City District & & $\begin{array}{c}-0.191 * * * \\
{[0.070]}\end{array}$ \\
\hline Placed in Dallas District & & $\begin{array}{c}0.033 \\
{[0.077]}\end{array}$ \\
\hline Placed in San Francisco District & & $\begin{array}{c}-0.181 * * \\
{[0.075]}\end{array}$ \\
\hline Observations & 1,126 & 1,126 \\
\hline Adjusted R-squared & 0.085 & 0.203 \\
\hline
\end{tabular}

Notes: The Table presents a linear probability model where the dependent variable is a dummy that equals 1 if a county was placed in other than its preferred district. The sample includes only counties that won by one of the 12 Reserve Bank cities. Counties with Reserve Banks are also omitted from the sample. Huber-White standard errors are provided in brackets. * denotes significance at $10 \% ; * *$ at $5 \%$ level and $* * *$ at $1 \%$ level. 
Table 8: Number of Correspondents Links to Cities with at least 10 Links

\begin{tabular}{|c|c|c|c|}
\hline Location & Links & Location & Links \\
\hline New York/Brooklyn & 7119 & Lincoln & 46 \\
\hline Chicago & 3080 & Seattle & 44 \\
\hline Philadelphia & 1552 & Pueblo & 42 \\
\hline St Louis & 1137 & Washington & 40 \\
\hline Minneapolis/St Paul & 721 & Oklahoma City & 39 \\
\hline Kansas City & 691 & Buffalo & 38 \\
\hline Pittsburgh & 645 & Salt Lake City & 37 \\
\hline Boston & 623 & Columbus & 37 \\
\hline Cincinnati & 449 & Jacksonville & 28 \\
\hline Albany & 412 & San Antonio & 20 \\
\hline Omaha & 392 & Birmingham & 20 \\
\hline Baltimore & 380 & Wilmington & 20 \\
\hline San Francisco & 361 & Fargo & 19 \\
\hline Dallas/Ft Worth & 240 & Peoria & 18 \\
\hline Cleveland & 201 & Waco & 15 \\
\hline Indianapolis & 176 & Wichita & 14 \\
\hline Denver & 156 & Macon & 14 \\
\hline Des Moines & 142 & Chattanooga & 14 \\
\hline Louisville & 139 & Knoxville & 12 \\
\hline Portland & 127 & Muskogee & 12 \\
\hline Houston & 119 & Fort Smith & 12 \\
\hline Los Angeles & 115 & Galveston & 11 \\
\hline Milwaukee & 100 & Norfolk & 11 \\
\hline Sioux City & 94 & Helena & 11 \\
\hline Spokane & 82 & Toledo & 11 \\
\hline St Joseph & 73 & Decatur & 10 \\
\hline Cedar Rapids & 71 & Duluth & 10 \\
\hline New Orleans & 69 & Sherman, TX & 10 \\
\hline Detroit & 64 & Tampa & 10 \\
\hline Nashville & 62 & Boise & 10 \\
\hline Richmond & 59 & & \\
\hline Atlanta & 55 & & \\
\hline Savannah & 50 & & \\
\hline
\end{tabular}

Note: The table includes all cities with 10 or more correspondent links as reported in Rand McNally Bankers Directory (January 1913). 
Table 9: Evidence on the Relationship Between Correspondent Links, Geographic Distance and County-Level Votes

\begin{tabular}{|c|c|c|c|c|c|}
\hline & $\begin{array}{c}\text { Number of } \\
\text { Non-Home } \\
\text { Counties Won }\end{array}$ & $\begin{array}{c}\text { Percent of } \\
\text { Counties Won } \\
\text { where Largest } \\
\text { Share of Corr. } \\
\text { Links were to } \\
\text { City }\end{array}$ & $\begin{array}{l}\text { Percent of } \\
\text { Counties Won } \\
\text { where City } \\
\text { Tied for Most } \\
\text { Corr. Links }\end{array}$ & $\begin{array}{c}\text { Percent of } \\
\text { Counties Won } \\
\text { where City } \\
\text { had Fewer } \\
\text { Corr. Links } \\
\text { than Another } \\
\text { City }\end{array}$ & $\begin{array}{l}\text { Percent of Counties } \\
\text { Won that were } \\
\text { Closer to City than } \\
\text { to any other Vote- } \\
\text { Receiving City }\end{array}$ \\
\hline Atlanta & 62 & $24.2 \%$ & $27.4 \%$ & $48.4 \%$ & $46.8 \%$ \\
\hline Baltimore & 37 & $62.2 \%$ & $29.7 \%$ & $8.1 \%$ & $29.7 \%$ \\
\hline Birmingham & 24 & $20.8 \%$ & $20.8 \%$ & $58.3 \%$ & $54.2 \%$ \\
\hline Boston & 42 & $92.9 \%$ & $4.8 \%$ & $2.4 \%$ & $66.7 \%$ \\
\hline Charlotte & 9 & $11.1 \%$ & $33.3 \%$ & $55.6 \%$ & $100.0 \%$ \\
\hline Chattanooga & 5 & $40.0 \%$ & $0.0 \%$ & $60.0 \%$ & $100.0 \%$ \\
\hline Chicago & 258 & $72.1 \%$ & $23.3 \%$ & $4.7 \%$ & $10.5 \%$ \\
\hline Cincinnati & 85 & $75.3 \%$ & $8.2 \%$ & $16.5 \%$ & $40.0 \%$ \\
\hline Cleveland & 28 & $85.7 \%$ & $7.1 \%$ & $7.1 \%$ & $50.0 \%$ \\
\hline Columbia & 13 & $30.8 \%$ & $7.7 \%$ & $61.5 \%$ & $61.5 \%$ \\
\hline Columbus & 2 & $50.0 \%$ & $0.0 \%$ & $50.0 \%$ & $100.0 \%$ \\
\hline Dallas/Ft Worth & 92 & $56.5 \%$ & $20.7 \%$ & $22.8 \%$ & $47.8 \%$ \\
\hline Denver & 44 & $56.8 \%$ & $22.7 \%$ & $20.5 \%$ & $88.6 \%$ \\
\hline Detroit & 13 & $92.3 \%$ & $0.0 \%$ & $7.7 \%$ & $76.9 \%$ \\
\hline Galveston & 1 & $0.0 \%$ & $100.0 \%$ & $0.0 \%$ & $0.0 \%$ \\
\hline Houston & 40 & $50.0 \%$ & $37.5 \%$ & $12.5 \%$ & $35.0 \%$ \\
\hline Indianapolis & 4 & $25.0 \%$ & $75.0 \%$ & $0.0 \%$ & $100.0 \%$ \\
\hline Jacksonville & 7 & $57.1 \%$ & $14.3 \%$ & $28.6 \%$ & $100.0 \%$ \\
\hline Kansas City & 150 & $86.7 \%$ & $7.3 \%$ & $6.0 \%$ & $24.7 \%$ \\
\hline Lincoln & 3 & $0.0 \%$ & $33.3 \%$ & $66.7 \%$ & $100.0 \%$ \\
\hline Los Angeles & 3 & $66.7 \%$ & $0.0 \%$ & $33.3 \%$ & $100.0 \%$ \\
\hline Louisville & 48 & $56.3 \%$ & $31.3 \%$ & $12.5 \%$ & $50.0 \%$ \\
\hline Memphis & 8 & $25.0 \%$ & $25.0 \%$ & $50.0 \%$ & $75.0 \%$ \\
\hline Milwaukee & 3 & $100.0 \%$ & $0.0 \%$ & $0.0 \%$ & $66.7 \%$ \\
\hline \multicolumn{6}{|l|}{ Minneapolis/St } \\
\hline Paul & 160 & $88.1 \%$ & $8.8 \%$ & $3.1 \%$ & $34.4 \%$ \\
\hline Montgomery & 1 & $0.0 \%$ & $100.0 \%$ & $0.0 \%$ & $100.0 \%$ \\
\hline Nashville & 17 & $47.1 \%$ & $41.2 \%$ & $11.8 \%$ & $52.9 \%$ \\
\hline New Orleans & 24 & $58.3 \%$ & $20.8 \%$ & $20.8 \%$ & $62.5 \%$ \\
\hline New York & 89 & - & - & - & $29.2 \%$ \\
\hline Omaha & 66 & $77.3 \%$ & $16.7 \%$ & $6.1 \%$ & $7.6 \%$ \\
\hline Philadelphia & 49 & $95.9 \%$ & $0.0 \%$ & $4.1 \%$ & $51.0 \%$ \\
\hline Pittsburgh & 37 & $89.2 \%$ & $2.7 \%$ & $8.1 \%$ & $86.5 \%$ \\
\hline Portland & 21 & $47.6 \%$ & $38.1 \%$ & $14.3 \%$ & $66.7 \%$ \\
\hline Richmond & 77 & $11.7 \%$ & $26.0 \%$ & $62.3 \%$ & $40.3 \%$ \\
\hline St Louis & 97 & $51.5 \%$ & $33.0 \%$ & $15.5 \%$ & $40.2 \%$ \\
\hline Salt Lake City & 11 & $54.5 \%$ & $9.1 \%$ & $36.4 \%$ & $100.0 \%$ \\
\hline San Antonio & 1 & $0.0 \%$ & $0.0 \%$ & $100.0 \%$ & $100.0 \%$ \\
\hline San Francisco & 46 & $80.4 \%$ & $10.9 \%$ & $8.7 \%$ & $52.2 \%$ \\
\hline Savannah & 11 & $36.4 \%$ & $18.2 \%$ & $45.5 \%$ & $45.5 \%$ \\
\hline Seattle & 14 & $42.9 \%$ & $21.4 \%$ & $35.7 \%$ & $92.9 \%$ \\
\hline Spokane & 9 & $55.6 \%$ & $11.1 \%$ & $33.3 \%$ & $100.0 \%$ \\
\hline Washington DC & 6 & $0.0 \%$ & $16.7 \%$ & $83.3 \%$ & $0.0 \%$ \\
\hline Wichita & 1 & $0.0 \%$ & $0.0 \%$ & $100.0 \%$ & $100.0 \%$ \\
\hline Weighted Avg. & 1,718 & $64.9 \%$ & $18.2 \%$ & $16.9 \%$ & $40.1 \%$ \\
\hline
\end{tabular}

Notes: The percentages are not mutually exclusive as a county could both be the closest and have the most correspondent links with a given city. Counties with tie votes and those without votes are omitted. Correspondents in New York City, Chicago, and St Louis are dropped from all cities. Correspondents from New York City are dropped from Chicago and St Louis. The weighted average is obtained by taking the ratio of the total number of correct counties to the total number of counties, and is thus a weighted average of the individual city fractions. 
Table 10: Linear Determinants of First Choice Votes and Counties Won By City

\begin{tabular}{|c|c|c|c|c|}
\hline & \multicolumn{2}{|c|}{ Ln(First Place Votes) } & \multicolumn{2}{|c|}{ Ln(Counties Won) } \\
\hline & $\begin{array}{c}\text { All Locations } \\
\text { (1) }\end{array}$ & $\begin{array}{c}\text { Without } \\
\text { NYC and } \\
\text { Chicago } \\
\text { (2) }\end{array}$ & $\begin{array}{c}\text { All Locations } \\
\text { (3) }\end{array}$ & $\begin{array}{c}\text { Without } \\
\text { NYC and } \\
\text { Chicago } \\
(4)\end{array}$ \\
\hline Ln(\# of Corr. Links) & $\begin{array}{c}0.442 * * * \\
{[0.161]}\end{array}$ & $\begin{array}{c}0.693 * * * \\
{[0.118]}\end{array}$ & $\begin{array}{l}0.300 * \\
{[0.165]}\end{array}$ & $\begin{array}{c}0.522 * * * \\
{[0.165]}\end{array}$ \\
\hline Population in 1910 & $\begin{array}{l}0.526^{* *} \\
{[0.208]}\end{array}$ & $\begin{array}{c}0.213 \\
{[0.182]}\end{array}$ & $\begin{array}{l}0.587 * * \\
{[0.250]}\end{array}$ & $\begin{array}{c}0.281 \\
{[0.266]}\end{array}$ \\
\hline $\begin{array}{l}\text { \%Change in Population } \\
1900-1910\end{array}$ & $\begin{array}{c}1.091 * * * \\
{[0.402]}\end{array}$ & $\begin{array}{c}1.044 * * * \\
{[0.386]}\end{array}$ & $\begin{array}{l}1.080 * * \\
{[0.483]}\end{array}$ & $\begin{array}{l}1.046 * * \\
{[0.475]}\end{array}$ \\
\hline $\begin{array}{l}\text { \%Change in National Bank } \\
\text { Capital 1903-1913 }\end{array}$ & $\begin{array}{l}-0.164 \\
{[0.176]}\end{array}$ & $\begin{array}{l}-0.126 \\
{[0.164]}\end{array}$ & $\begin{array}{l}-0.309 \\
{[0.200]}\end{array}$ & $\begin{array}{l}-0.280 \\
{[0.192]}\end{array}$ \\
\hline $\begin{array}{l}\text { Ln(National Bank Capital) } \\
\text { in } 1913\end{array}$ & $\begin{array}{l}0.206^{*} \\
{[0.115]}\end{array}$ & $\begin{array}{c}0.096 \\
{[0.087]}\end{array}$ & $\begin{array}{l}0.229 * \\
{[0.118]}\end{array}$ & $\begin{array}{c}0.136 \\
{[0.100]}\end{array}$ \\
\hline Ln(State Bank Capital) in 1913 & $\begin{array}{c}0.022 \\
{[0.027]}\end{array}$ & $\begin{array}{c}0.023 \\
{[0.023]}\end{array}$ & $\begin{array}{c}0.015 \\
{[0.029]}\end{array}$ & $\begin{array}{c}0.016 \\
{[0.023]}\end{array}$ \\
\hline $\begin{array}{l}\text { Ln(Railroads Per Person } \\
\text { in 1910) }\end{array}$ & $\begin{array}{l}-0.045 \\
{[0.052]}\end{array}$ & $\begin{array}{c}-0.008 \\
{[0.049]}\end{array}$ & $\begin{array}{l}-0.078 \\
{[0.060]}\end{array}$ & $\begin{array}{l}-0.047 \\
{[0.060]}\end{array}$ \\
\hline $\begin{array}{l}\text { Ln(Telephones Per Person } \\
\text { in 1907) }\end{array}$ & $\begin{array}{c}0.005 \\
{[0.006]}\end{array}$ & $\begin{array}{c}0.004 \\
{[0.006]}\end{array}$ & $\begin{array}{c}0.005 \\
{[0.008]}\end{array}$ & $\begin{array}{c}0.004 \\
{[0.009]}\end{array}$ \\
\hline $\begin{array}{l}\text { Ln(City's Bradstreets Names } \\
\text { in 1914) }\end{array}$ & $\begin{array}{c}-0.072 * * * \\
{[0.025]}\end{array}$ & $\begin{array}{c}-0.061 * * * \\
{[0.022]}\end{array}$ & $\begin{array}{c}-0.063 * * \\
{[0.027]}\end{array}$ & $\begin{array}{c}-0.052 * * \\
{[0.025]}\end{array}$ \\
\hline Urban Center Dummy & $\begin{array}{l}0.690 * \\
{[0.379]}\end{array}$ & $\begin{array}{l}0.695 * \\
{[0.366]}\end{array}$ & $\begin{array}{c}0.421 \\
{[0.420]}\end{array}$ & $\begin{array}{c}0.440 \\
{[0.406]}\end{array}$ \\
\hline Reserve City Dummy & $\begin{array}{c}0.740 \\
{[0.520]}\end{array}$ & $\begin{array}{c}0.153 \\
{[0.422]}\end{array}$ & $\begin{array}{l}1.155^{*} \\
{[0.621]}\end{array}$ & $\begin{array}{c}0.633 \\
{[0.580]}\end{array}$ \\
\hline $\begin{array}{l}\text { State Fixed Effects? } \\
\text { Observations } \\
\text { Adjusted R-squared }\end{array}$ & $\begin{array}{c}\text { Yes } \\
173 \\
0.824\end{array}$ & $\begin{array}{c}\text { Yes } \\
171 \\
0.832\end{array}$ & $\begin{array}{c}\text { Yes } \\
173 \\
0.749\end{array}$ & $\begin{array}{c}\text { Yes } \\
171 \\
0.742\end{array}$ \\
\hline
\end{tabular}

Notes: The table presents the results of a linear regression model where the dependent variable is either the log of first place votes or counties won. The sample includes all cities with an urban population above 30,000 in 1910 . Huber-White standard errors are provided in brackets. * denotes significance at $10 \%$; ** at $5 \%$ level and *** at $1 \%$ level. 


\section{Figure 1: National Banks in 1914}

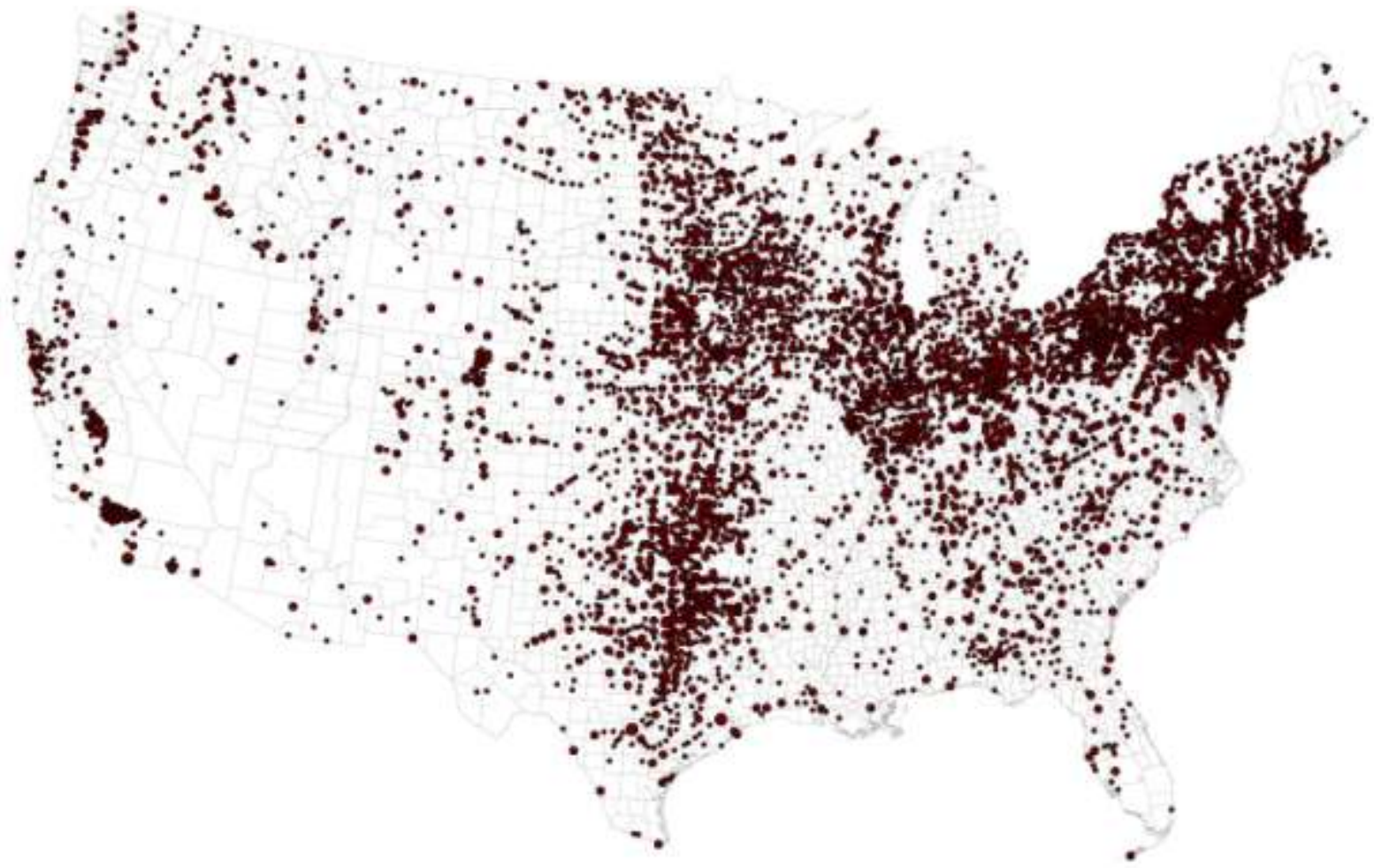

Notes: The figure displays the location of every national bank in operation in 1914. Banks obtained from

Comptroller of the Currency's Annual Report in 1914. Dot size is proportionate to the number of banks in the city. 
Figure 2: Fed Districts and Voting Behavior

Panel A: Fed Districts 1914

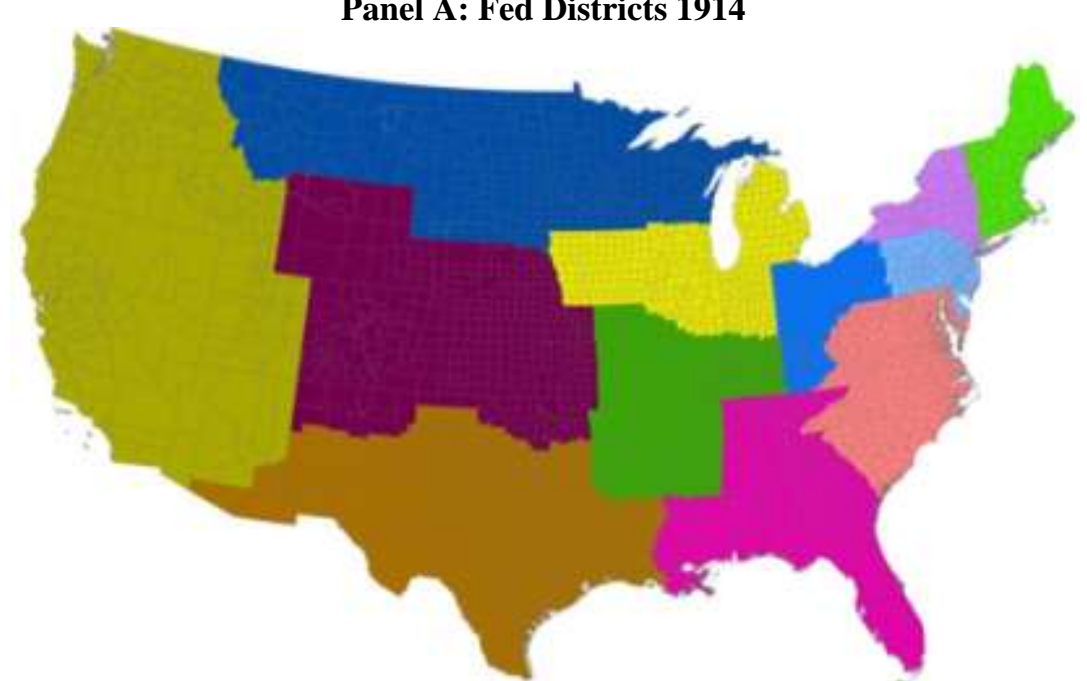

Panel B: Winning City in County Votes (Only Reserve Cities)

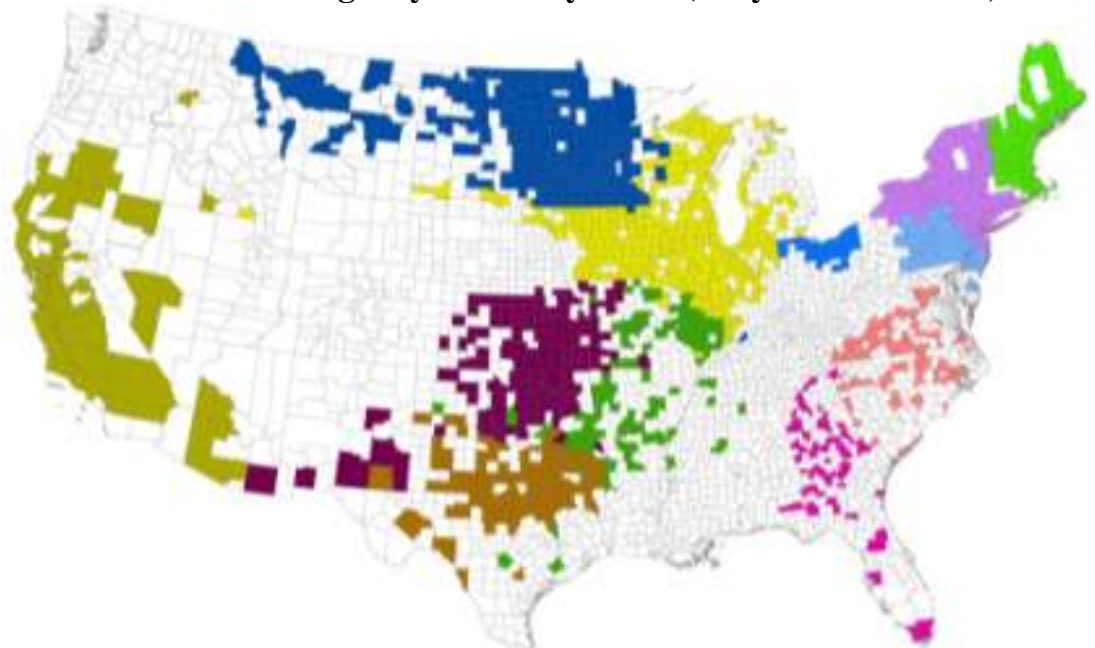

Panel C: Winning City in County Votes (Combining Reserve Cities and Branches)

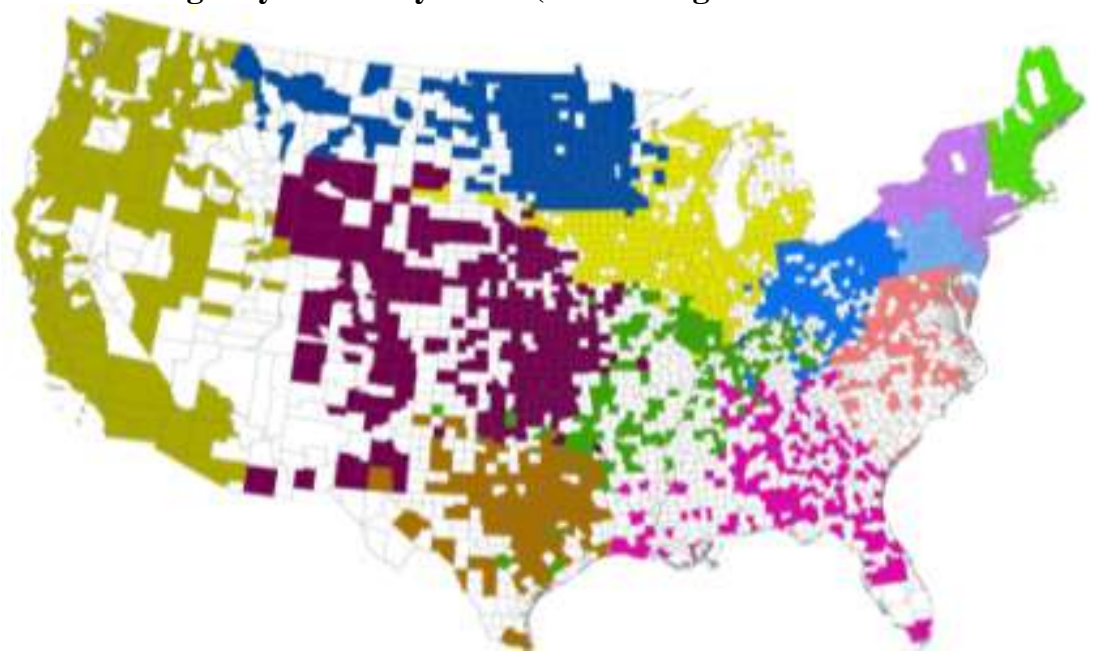

Notes: Panel A displays the original Fed district boundaries. Panel B displays the results of the county-level votes only for Reserve Cities. Panel C displays the result of the county-level votes for Reserve Bank Cities and branches. Colors denote the district. 
Figure 3: Examples of Correspondent Networks By City in 1913 New York

Chicago

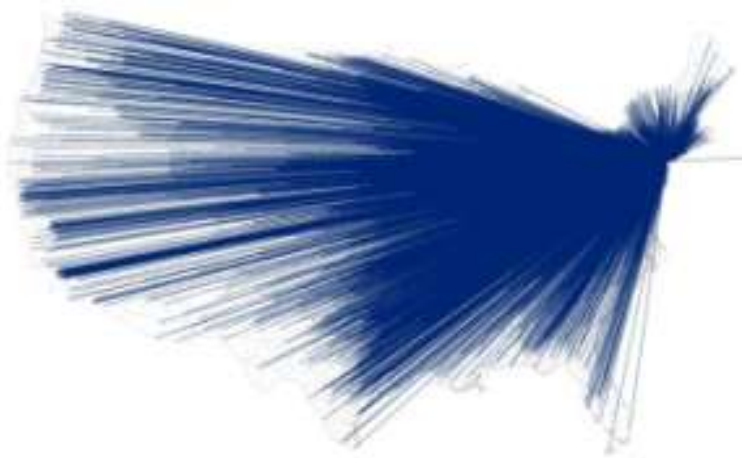

Boston

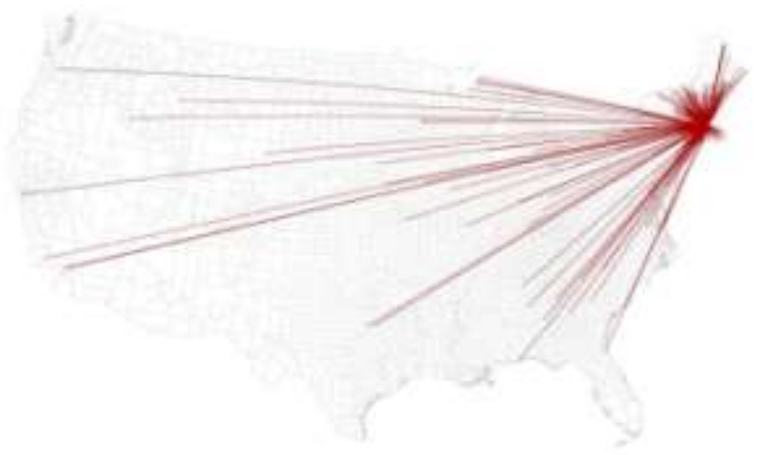

San Francisco

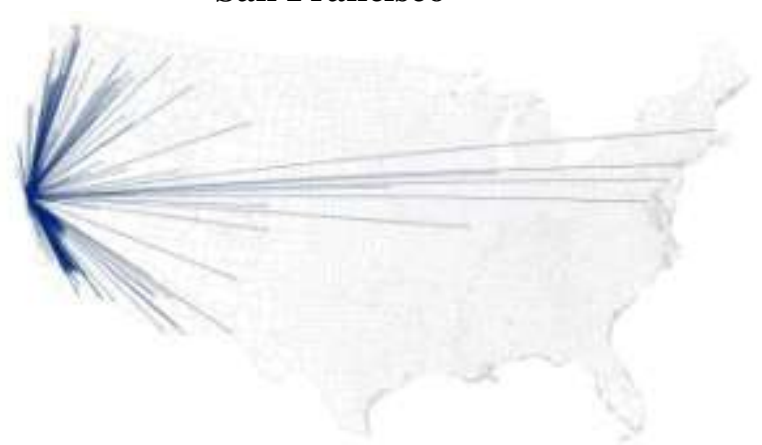

Atlanta

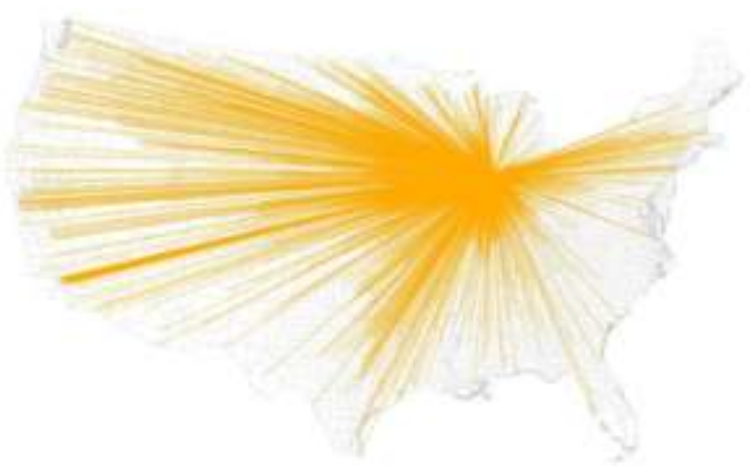

\section{Philadelphia}

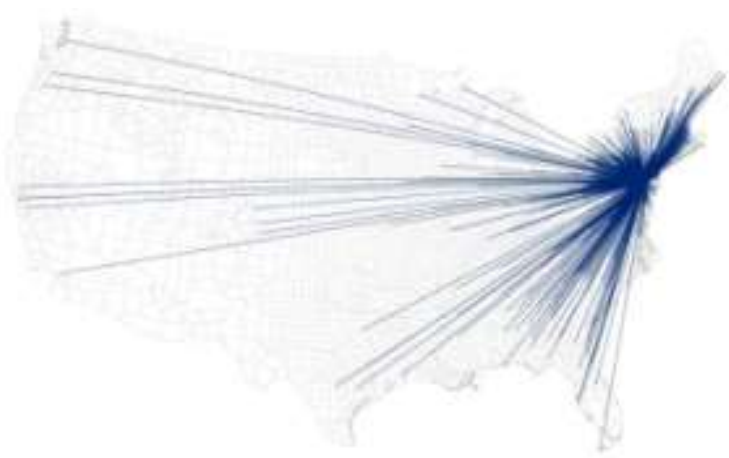

Minneapolis \& St Paul
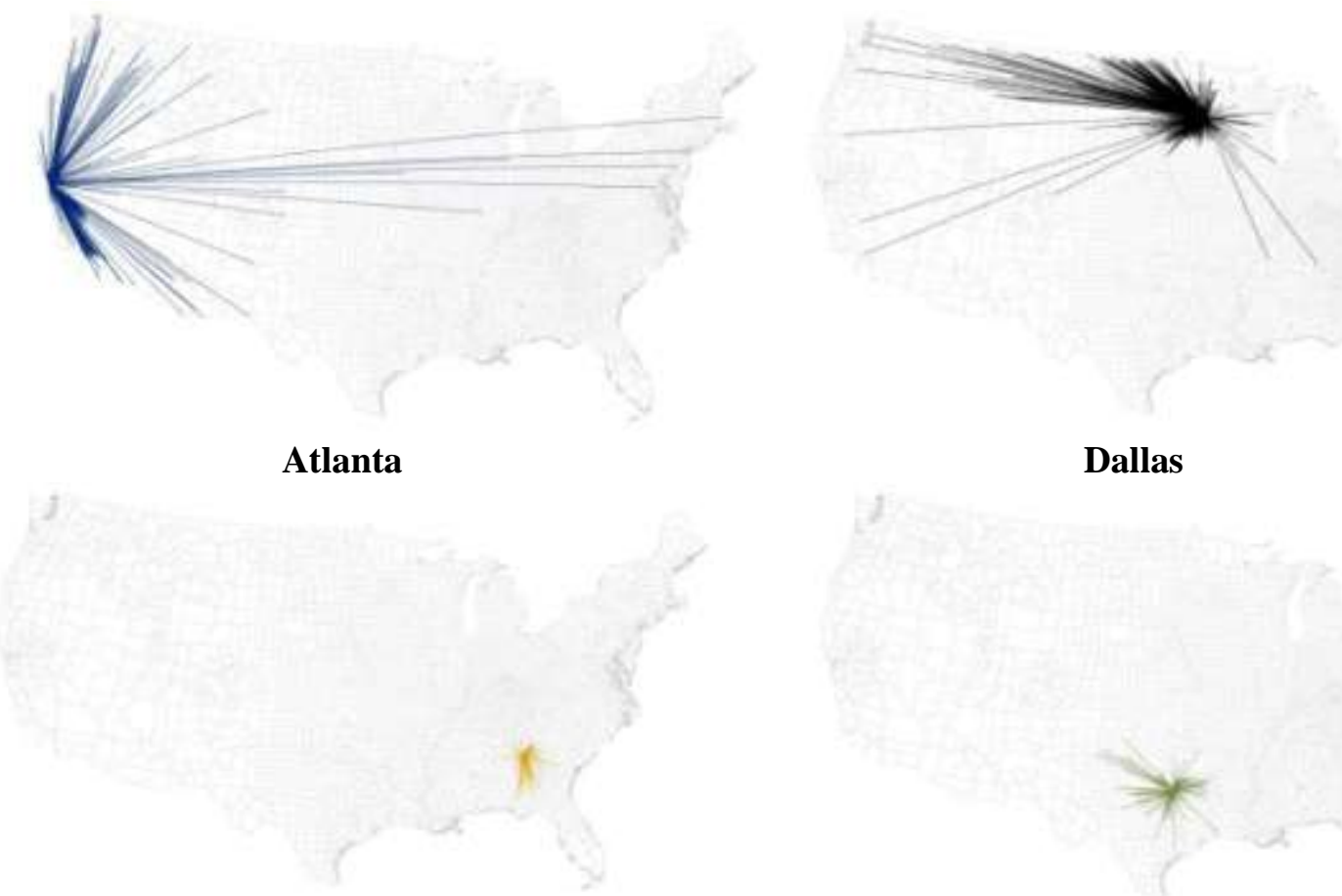

Dallas

Notes: Figures display correspondent connections at the city-level for the various listed cities. 
Figure 4: Correspondent Networks Of Controversial Picks By City in 1913

Cleveland

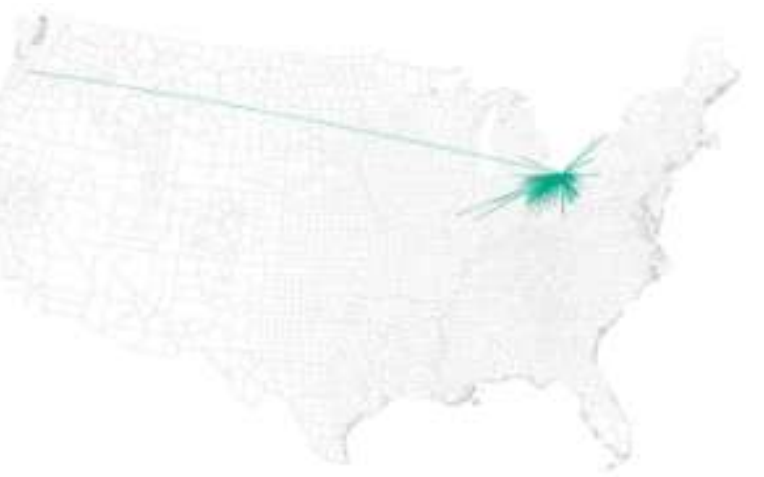

Pittsburgh

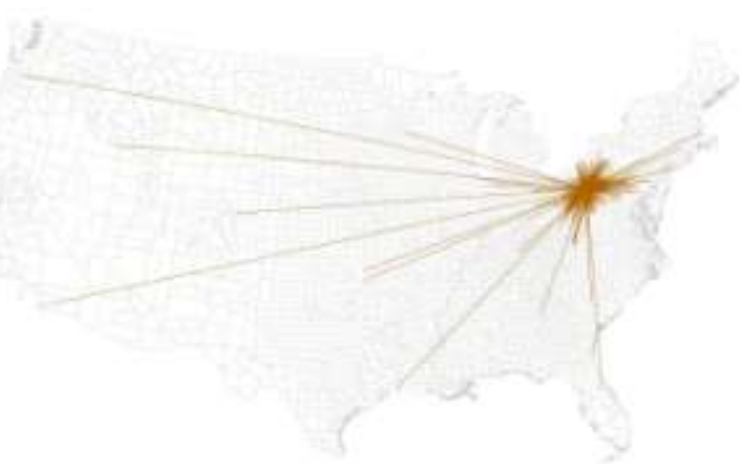

\section{Cincinnati}

3
Richmond

\section{Baltimore}

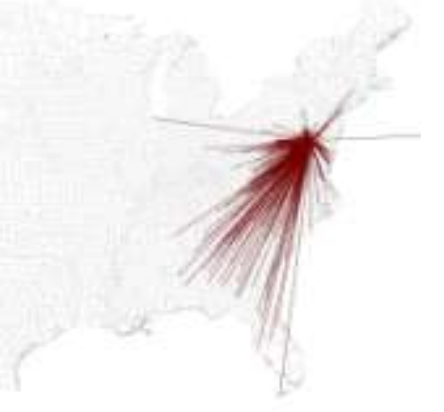

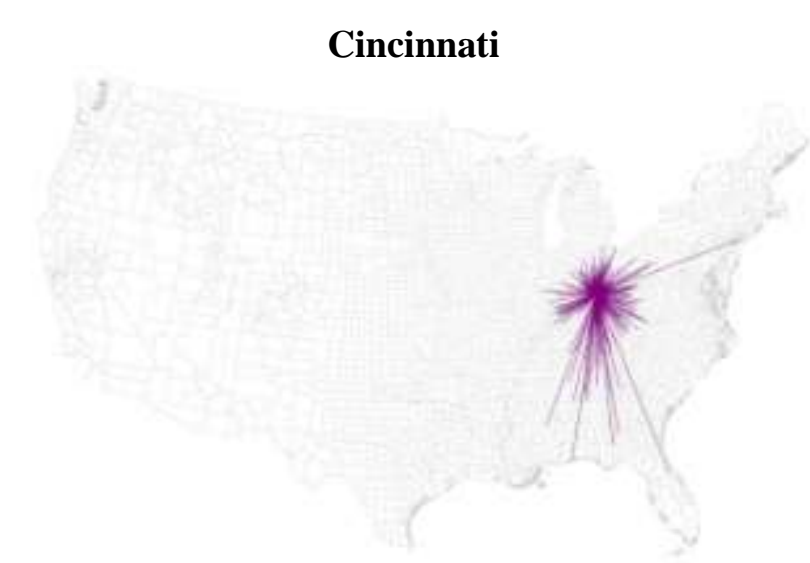

Notes: Figures display correspondent connections at the city-level for the various listed cities. 